\title{
The New Keynesian PhiLlips Curve AND the ROLE OF EXPECTATIONS: EVIDENCE FROM THE IFO WORLD ECONOMIC SURVEY
}

\author{
STEFFEN HENZEL \\ TIMO WOLLMERSHAEUSER
}

CESIFO WORKING PAPER NO. 1694

CATEGORY 6: MONETARY POLICY AND INTERNATIONAL FINANCE

MARCH 2006

An electronic version of the paper may be downloaded

- from the SSRN website:

www.SSRN.com

- from the CESifo website:

www.CESifo-group.de 


\title{
The New Keynesian PHILliPs CURVE AND THE ROLE OF EXPECTATIONS: EVIDENCE FROM THE IFO WORLD ECONOMIC SURVEY
}

\begin{abstract}
We provide evidence on the fit of the hybrid New Keynesian Phillips curve for selected euro zone countries, the US and the UK. Instead of imposing rational expectations and estimating the Phillips curve by the Generalized Method of Moments, we follow Roberts (1997) and Adam and Padula (2003) and use direct measures of inflation expectations. The data source is the Ifo World Economic Survey, which quarterly polls economic experts about their expected future development of inflation. Our main findings are as follows: (i) In comparison with the rational expectations approach, backward-looking behaviour turns out to more relevant for most countries in our sample. (ii) The use of survey data for inflation expectations yields a positive slope of the Phillips curve when the output gap is used as a measure for marginal cost.
\end{abstract}

JEL Code: C52, E31.

Keywords: inflation expectations, survey data, euro zone, Phillips curve.

Steffen Henzel

Ifo Institute for Economic Research at the University of Munich

Poschingerstr. 5

81679 Munich

Germany

henzel@ifo.de
Timo Wollmershaeuser

Ifo Institute for Economic Research

at the University of Munich

Poschingerstr. 5

81679 Munich

Germany

wollmershaeuser@ifo.de

March 17, 2006

We would like to thank participants at two internal research seminars at the Universities of Munich and Würzburg, the 2005 Annual Meetings of the Verein für Socialpolitik, the Canadian Economics Association and the Austrian Economic Association for comments and suggestions. 


\section{Introduction}

The relationship between inflation and real variables is of crucial importance for understanding the effects of monetary policy on inflation. In recent years, some kind of consensus has emerged, generally referred to as New Keynesian macroeconomics, that integrates Keynesian elements (imperfect competition, nominal rigidities) into a dynamic general equilibrium framework traditionally used in the Real Business Cycle literature. The nature of inflation dynamics is arguably the most distinctive feature of the New Keynesian paradigm. It is captured by the so-called New Keynesian Phillips curve which is based on Calvo's (1983) model of staggered price setting and which expresses current inflation as a function of expected future inflation and a measure of firms' real marginal costs. While theoretically appealing, a number of authors (e.g. Fuhrer and Moore, 1995) criticized this version of the Phillips curve since the implied 'jump' behavior of inflation was completely at odds with the hump-shaped behavior that can be observed in VAR analyses. As a consequence, Galí and Gertler (1999) extended Calvo's theoretical framework to the so-called hybrid New Keynesian Phillips curve (HNKPC) by allowing for a fraction of firms that set prices according to a backward-looking rule-of-thumb.

The empirical findings are encouraging for the New Keynesian Phillips curve. Empirical work mainly centers around the question of which variable to use for measuring real activity and whether backward-looking behavior is relevant. Concerning the first question, theory tells us that real marginal costs are the driving force underlying changes in inflation. In a recent survey article Galí (2003) emphasizes that empirical results are promising when the New Keynesian Phillips curve is estimated in a way consistent with theory, implying that labor income share is used instead of detrended GDP as a proxy for real marginal costs. Concerning the second question he continues: "Although backward-looking behavior is often statistically significant, it appears to have limited quantitative importance. In other words, although the baseline pure forward-looking model is rejected on statistical grounds, it is still likely to be a reasonable first approximation to the inflation dynamics of both Europe and the United States." (ibid., p. 162).

The standard econometric tool for estimating the New Keynesian Phillips curve is the Instrumental Variables or, more generally, the Generalized Method of Moments (GMM). Expectations about future variables are replaced by their ex-post realizations, and expectational errors are assumed to be uncorrelated with all variables in the information set of agents available at the time expectations are formed. In other words, expectations are assumed to be rational. 
There is, however, an ongoing debate in the recent literature about the appropriateness of the GMM technique. As mentioned by Mavroeidis (2005) and Rudd and Whelan (2005), GMM estimates may overstate the degree of forward-looking behavior if the true expectation formation process is nonrational in the sense that important variables are omitted. In conjunction with the use of instrument variables that are correlated with future inflation, this omission leads to inconsistent parameter estimates that bias upwards the coefficient of expected inflation. Consequently, Mavroeidis (2005) and Rudd and Whelan (2005) argue that the small role for lagged inflation in the HNKPC identified by Galí and Gertler (1999) (and later by Galí et al. 2001, $2003,2005)$ is econometrically unreliable in that they ignore other variables that may influence inflation.

The contribution of this paper is twofold. On a theoretical level we derive the HNKPC under the assumption that firms may have non-rational expectations. Available evidence from surveys suggests that inflation expectations are in many cases biased and inefficient predictors of future inflation, thereby questioning the assumption of rationality (see Roberts, 1997, and the papers cited there). We extend the theoretical framework developed by Adam and Padula (2003) by allowing for the existence of both, forward-looking and backward-looking firms. On an empirical level we follow Roberts (1997) and Adam and Padula (2003) and use direct measures of inflation expectations, instead of imposing rational expectations and estimating the Phillips curve by GMM. The data source is the Ifo World Economic Survey which quarterly polls economic experts about their expected future development of inflation. The main results are that (i) in comparison with the rational expectations approach backward-looking behavior turns out to be more relevant for most countries in our sample and that (ii) the use of survey data for inflation expectations yields a positive slope of the Phillips curve when the output gap is used as a measure for marginal cost. Real unit labor costs seem to be the driving variable for inflation only in two of the countries considered in this study.

The paper is organized as follows. In section 2 we present the standard version of the HNKPC that results from a rational expectations approach and we modify it in a way that accounts for subjective and potentially nonrational expectations of firms. Section 3 gives an overview of the data. The main focus is on the presentation of the inflation expectations from the Ifo WES, but we also briefly discuss the variables used as proxies for real marginal costs. Our estimation results and a comparison with other empirical work (mainly using the rational expectations approach) are presented in section 4 . Finally, section 5 summarizes the main results and concludes. 


\section{The Hybrid New Keynesian Phillips Curve}

\subsection{Rational Expectations}

The version of the HNKPC that is mostly used in the literature has been introduced by Galí and Gertler (1999) and extended by Galí, Gertler, and López-Salido (2001). It is based on Calvo's (1983) staggered price setting framework in which each firm has a probability $1-\theta$ of being able to reset its price in any given period, independently of the time elapsed since the most recent price adjustment. In contrast to Calvo (1983), however, they assume that of those firms being able to adjust prices in a given period, there is only a fraction of firms $1-\omega$ that sets prices optimally in a forward-looking manner. The remaining part uses a rule-of-thumb that simply augments last period's average reset price by the inflation rate prevailing in that period. It can then be shown that the HNKPC is given by

$$
\pi_{t}=\gamma_{f} E_{t}\left[\pi_{t+1}\right]+\gamma_{b} \pi_{t-1}+\lambda m c_{t}+\varepsilon_{t}
$$

where $\pi_{t}$ denotes the inflation rate, $E[\cdot]$ the rational expectations operator, and $m c_{t}$ the logarithm of real marginal costs, and where the coefficients can be expressed in terms of the structural parameters

$$
\begin{gathered}
\gamma_{f}=\frac{\beta \theta}{\theta+\omega[1-\theta(1-\beta)]}, \\
\gamma_{b}=\frac{\omega}{\theta+\omega[1-\theta(1-\beta)]}, \\
\lambda=\frac{(1-\omega)(1-\theta)(1-\beta \theta)}{\theta+\omega[1-\theta(1-\beta)]} .
\end{gathered}
$$

$\beta$ is the discount factor of the firms' intertemporal maximization problem. An important assumption underlying the derivation of the structural parameters was that firms operate under monopolistic competition with a Cobb-Douglas production technology and constant returns to scale. If returns to scale are decreasing, Galí, Gertler, and López-Salido (2001) showed that $\lambda$ additionally becomes a function of the labor elasticity of production and the price elasticity of demand.

This very general formulation of the Phillips curve comprises two special cases. First, when the discount factor $\beta$ is restricted to unity, $\gamma_{f}+\gamma_{b}=1$, which implies that in the long-run the Phillips curve is vertical. Second, when $\omega=0$ all firms set their prices optimally and the model converges to the pure forward-looking New Keynesian Phillips curve $\left(\gamma_{f}=\beta, \gamma_{b}=0\right.$, $\lambda=[(1-\theta)(1-\beta \theta)] / \theta)$. 


\subsection{Subjective Expectations}

As in the previous section we distinguish between two groups of firms: forwardlooking firms which set prices according to an intertemporal optimization procedure, and backward-looking firms which set prices according to a simple rule-of-thumb. The main difference to the previous section is the way forward-looking firms form their expectations. Instead of imposing rational expectations (i.e. all firms form expectations homogenously, using the same model and the same information set), we allow for subjective expectations of each single forward-looking firm which may be rational or not and which may be heterogeneous across firms.

In the following we will derive the HNKPC under the assumption that firms form subjective expectations. We will extend the theoretical framework of Adam and Padula (2003) by explicitly introducing backward-looking firms. In contrast to their paper which describes the price-setting behavior of firms from the point of view of professional forecasters, we assume that the source of potential non-rationalities in expectations are the firms themselves. This has the advantage that we can continue to distinguish between two types of firms as in the case of rational expectations. If we had extended the professional forecasters' approach of Adam and Padula (2003), we would have faced the problem of finding an economic rationale for the additional consideration of $\pi_{t-1}$ in the Phillips curve. The reason for this is, that professional forecasters should take into account the existence of backward-looking firms when forming their expectations.

In accordance with the rational expectations approach the starting point is Calvo's (1983) staggered price setting framework which defines the log of the aggregate price level $p_{t}$ as

$$
p_{t}=(1-\theta) p_{t}^{*}+\theta p_{t-1}
$$

where $p_{t}^{*}$ is the average reset price and $1-\theta$ the probability that firms reset prices. The average reset price is a weighted sum of the average price set by forward-looking firms and the average price set by backward-looking firms

$$
p_{t}^{*}=(1-\omega) \frac{1}{I} \sum_{i=1}^{I} p_{t}^{f, i}+\omega \frac{1}{J} \sum_{i=1}^{J} p_{t}^{b, i}
$$

where $I(J)$ is the number of forward-looking (backward-looking) firms, $\omega$ the fraction of backward-looking firms $(\omega=J /(I+J))$, and $p_{t}^{b, i}\left(p_{t}^{f, i}\right)$ the price set by the backward-looking (forward-looking) firm $i$. All firms which set prices in a backward-looking manner, follow an identical rule-of-thumb 
according to which last period's average reset price is simply corrected by lagged inflation. Forming the average of all backward-looking firms gives

$$
p_{t}^{b}=\frac{1}{J} \sum_{i=1}^{J} p_{t}^{b, i}=p_{t-1}^{*}+\pi_{t-1} .
$$

Firms which behave in a forward-looking manner, maximize expected discounted profits given technology, factor prices and the constraint on price adjustment (defined by $1-\theta$ ) which results in the following log-linear rule:

$$
\begin{aligned}
p_{t}^{f, i} & =(1-\beta \theta) F_{t}^{i}\left[\sum_{k=0}^{\infty}(\beta \theta)^{k}\left(m c_{t+k}+p_{t+k}\right)\right]= \\
& =(1-\beta \theta)\left(m c_{t}+p_{t}\right)+\beta \theta F_{t}^{i}\left[p_{t+1}^{f, i}\right],
\end{aligned}
$$

where $F_{t}^{i}[\cdot]$ denotes the subjective expectations operator of firm $i{ }^{1}$ While individual firms produce differentiated products under monopolistic competition, they are all assumed to have the same Cobb-Douglas production technology and to face demand curves with constant and equal demand elasticities. The crucial problem now is the aggregation of individual prices set by forward-looking firms. Following Adam and Padula (2003) we assume that firm $i$ forms expectations about other firms' optimum prices and aggregates them to the average forward-looking price:

$$
F_{t}^{i}\left[p_{t+1}^{f}\right]=F_{t}^{i}\left[\frac{1}{I} \sum_{h=1}^{I} p_{t+1}^{f, h}\right] .
$$

Defining the average current forward-looking price by

$$
p_{t}^{f}=\frac{1}{I} \sum_{h=1}^{I} p_{t}^{f, h}
$$

and assuming that the 'law of iterated expectations' holds which implies that agents do not expect that current forecasts of future variables $z$ will be revised in a particular direction in the next period

$$
F_{t}^{i}\left[F_{t+1}^{h}\left[z_{t+s}\right]-F_{t}^{h}\left[z_{t+s}\right]\right]=0 \quad \forall i, h, s>0,
$$

Adam and Padula (2003) show that equation (6) can be expressed as

$$
F_{t}^{i}\left[\pi_{t+1}^{f}\right]=(1-\beta \theta)\left(F_{t}^{i}\left[p_{t+1}^{f}\right]-m c_{t}-p_{t}\right),
$$

\footnotetext{
${ }^{1}$ Apart from the $F_{t}^{i}[\cdot]$ operator equation (5) is identical with the optimum pricing rule under rational expectations. For a derivation see Galí and Gertler (1999) and Galí, Gertler, and López-Salido (2001).
} 
where $\pi_{t+1}^{f}=p_{t+1}^{f}-p_{t}^{f}$. In order to get this equation they took the difference between equation (6) and (7), replaced $p_{t}^{f, h}$ with the first expression of equation (5) and applied the law of iterated expectations (see appendix A).

Combining equations (2), (3) and (4) gives a relationship between $p_{t}^{f}$ and $p_{t}$ (see appendix B),

$$
p_{t}^{f}=\frac{p_{t}+(\theta \omega-2 \omega-\theta) p_{t-1}+\omega p_{t-2}}{(1-\theta)(1-\omega)}
$$

which can be shifted one period forward by applying the $F_{t}^{i}[\cdot]$ operator:

$$
F_{t}^{i}\left[p_{t+1}^{f}\right]=\frac{F_{t}^{i}\left[p_{t+1}\right]+(\theta \omega-2 \omega-\theta) p_{t}+\omega p_{t-1}}{(1-\theta)(1-\omega)} .
$$

Inserting equations (10) and (11) into equation (9) and aggregating over all subjective expectations, $\bar{F}_{t}[\cdot]=(1 / I) \sum_{i=1}^{I} F_{t}^{i}[\cdot]$, finally gives the HNKPC based on average subjective expectations (see appendix $\mathrm{C}$ ),

$$
\pi_{t}=\gamma_{f} \bar{F}_{t}\left[\pi_{t+1}\right]+\gamma_{b} \pi_{t-1}+\lambda m c_{t}
$$

where $\pi_{t}=p_{t}-p_{t-1}$. Note that equation (12) is identical with the specification derived under rational expectations, except for the way expectations are formed.

\section{Data Description}

\subsection{Inflation Expectations from the Ifo World Eco- nomic Survey}

Subjective inflation expectations are taken from the Ifo World Economic Survey (WES) which assesses trends in the world economy by polling transnational as well as national organizations worldwide about economic developments. It is conducted in co-operation of Ifo Institute for Economic Research and the International Chamber of Commerce (ICC) in Paris. The questionnaire of the WES which is distributed every quarter (January, April, July and October) and which was first conducted in March 1983 asks participants to give their assessment of the general economic situation and expectations regarding important macroeconomic indicators of the country they inhabit. Currently, the WES asks about 1100 experts in 90 countries.

A question on the expected inflation rate, which is in the focus of the present paper, was only included since July 1991. Survey participants are asked to give their expectations on the inflation rate by the end of the next six 
months. They indicate UP for an expected rise in the inflation rate, SAME for no change in the inflation rate and DOWN for an expected fall in the inflation rate by the end of the next six months. The questionnaire therefore reveals qualitative information on the participants' expectations. In Henzel and Wollmershäuser (2006) we presented a new methodology for the quantification of qualitative survey data. Traditional conversion methods, such as the Carlson and Parkin (1975) method or the time-varying parameters model of Seitz (1988), require very restrictive assumptions concerning the expectations formation process of survey respondents. Above all, the unbiasedness of expectations, which is a necessary condition for rationality, is imposed. Our approach avoids this assumption. The novelty was the way the boundaries inside of which survey respondents expect the variable under consideration to remain unchanged are determined. Instead of deriving these boundaries from the statistical properties of the reference time-series (which necessitates the unbiasedness assumption), we directly queried them from survey respondents by a special question in the Ifo WES. The new methodology was then applied to expectations about the future development of inflation obtained from the Ifo WES.

For Germany, France, Italy, the Euro zone ${ }^{2}$, the UK and the US the converted inflation expectations and the actual inflation rate are shown in figure 1. Inflation rates are taken from the OECD database, except for Euro zone inflation which was taken from Eurostat. Note that there are two outliers in the expectations time-series, namely in France (third quarter of 2000) and in Italy (second quarter of 1996), for which we controlled in our empirical analysis below by adding a dummy variable to the regression. The occurrence of these outliers is an unavoidable shortcoming of all conversion methods, when at a given point in time the assumption of normally distributed survey responses is violated. ${ }^{3}$ Inflation expectations from the Ifo WES are 6-months-ahead inflation expectations which are queried every three months in the first two weeks of January, April, July and October. In Henzel and Wollmershäuser (2006) we showed that the information set that is available to the survey respondents at the time they fill in the questionnaire is the past quarter (that is the first quarter for the questionnaires returned at the beginning of April, the second quarter for the questionnaires returned at the

\footnotetext{
${ }^{2}$ Euro zone inflation expectations have been calculated as a weighted sum of the responses for the individual member countries. The weights are the country weights used by Eurostat to calculate the Harmonized Index of Consumer Prices for the Euro zone. See Henzel and Wollmershäuser (2006) for further details.

${ }^{3}$ In the case of France, for example, in the October 2000 survey 13 out of 21 respondents indicated UP and 7 indicated DOWN. The problem was that only 1 respondent expected inflation to remain the same, which is a clear violation of the normality assumption.
} 
beginning of July, and so on). Thus, the April survey produces inflation expectations $\bar{F}_{t} \pi_{t+2}$, where $t$ refers to the first quarter and $t+2$ to the third quarter. As in a quarterly Phillips curve model the required expectation's horizon should be a quarter of a year, it would be more convenient to use the Ifo WES 6-months-ahead inflation expectations together with semiannual data. In order to see whether the frequency of the data matters for the empirical results, we ran regressions using both, quarterly and semiannual data. As the estimated coefficients were almost identical, we decided to present only the results of the regressions that were obtained using quarterly data. By using the 6-months-ahead inflation expectations as proxies for 3month expectations we implicitly assumed that forecaster's expectations are the same for each of the two upcoming 3-month periods (see also Roberts, 1997, on this point).

As most of the countries considered in this paper belonged to the European Monetary System, the data starts in the first quarter of 1993 in order to exclude the crisis which took place in September 1992. Compared to most other empirical Phillips curve studies this rather short estimation period is a novelty (see table 11 for a summary of other papers). ${ }^{4}$

Using survey data for inflation expectations instead of imposing rational expectations when estimating a Phillips curve relationship should only produce different results, if survey expectations are not being formed rationally. The reason why we are questioning the rationality of survey expectations is due to the mixed evidence reported in the literature. Many papers that have examined survey measures of inflation expectations have concluded that these expectations are not rational in the sense of Muth (1961) (see for example Roberts, 1997, and the papers cited there).

A necessary condition for rational expectations is the unbiasedness of expectations. In order to find out whether Ifo WES expectations are unbiased predictors of future inflation we regressed the forecast error (defined as $\pi_{t}-$ $\left.\bar{F}_{t-2} \pi_{t}\right)$ on a constant $c$ and tested whether it is significantly different from zero. Table (1) reveals that in the Euro zone, France and Germany inflation expectations were unbiased during the period 1993:1 to 2004:2. By contrast, in the UK, the US and Italy expectations do not fulfill the necessary condition for rationality. ${ }^{5}$ From the negative sign of the constant we can conclude that expectations were biased upwards throughout the period of disinflation in

\footnotetext{
${ }^{4}$ As was already mentioned in the introduction, the standard estimation technique in these papers is GMM. However, it is well known that GMM estimates suffer from a serious small-sample bias, which explains why most samples start in 1970 or earlier.

${ }^{5}$ Using the Livingston Survey of Professional Forecasters (which queries quantitative inflation expectations) Adam and Padula (2003) also find that expectations in the US were biased during the nineties.
} 

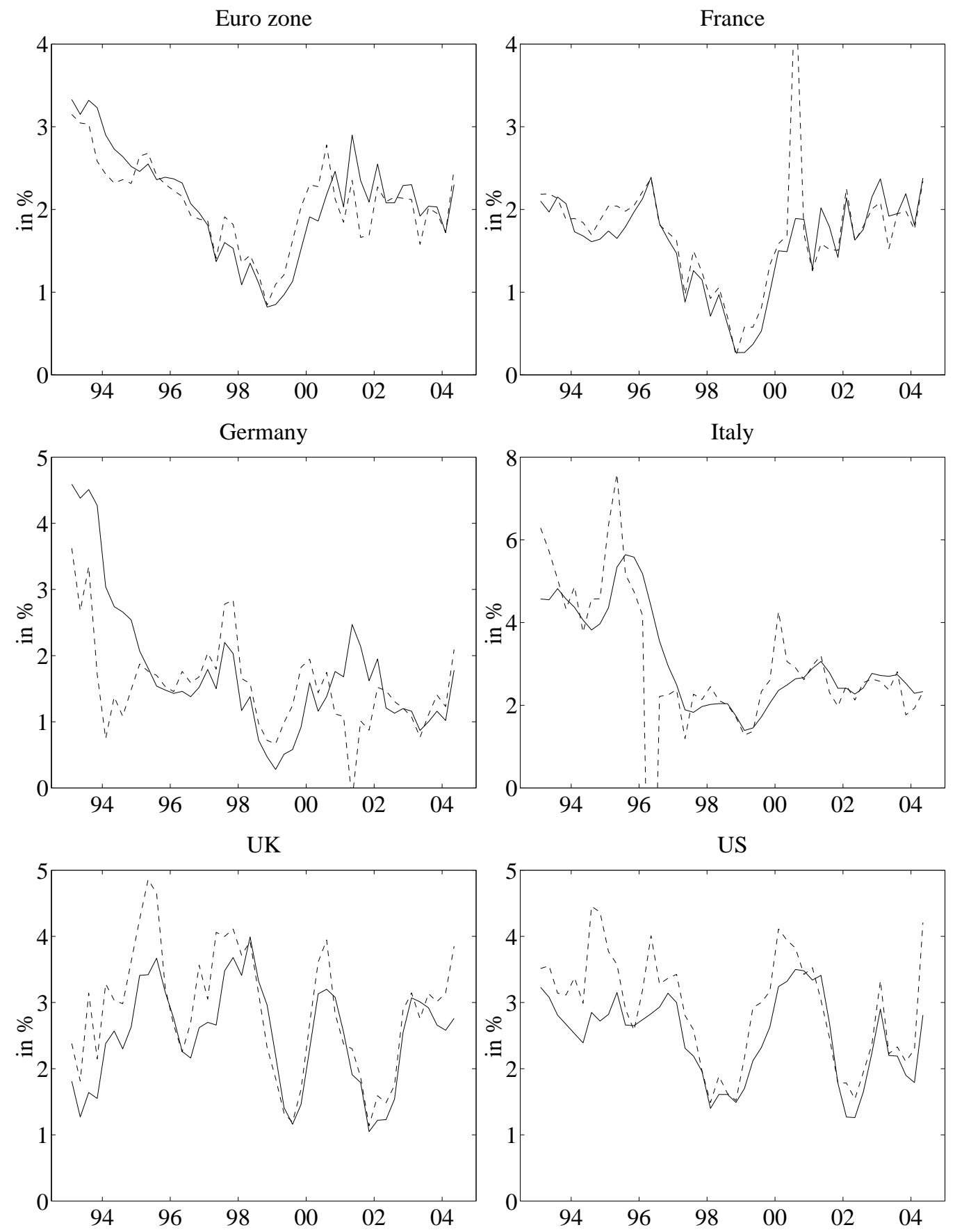

Figure 1: Actual (solid line) and expected (dashed line) inflation 
the beginning of the 1990s.

\begin{tabular}{l|cccccc}
\hline \hline & $\begin{array}{l}\text { Euro } \\
\text { zone }\end{array}$ & France & $\begin{array}{c}\text { Ger } \\
\text {-many }\end{array}$ & Italy & UK & US \\
& 0.05 & -0.04 & 0.13 & -0.27 & -0.37 & -0.43 \\
$\mathrm{c}$ & {$[0.46]$} & {$[0.66]$} & {$[0.49]$} & {$[0.03]$} & {$[0.02]$} & {$[0.00]$} \\
\hline $\mathrm{LM}(2)$ & 0.82 & 0.77 & 0.00 & 0.96 & 0.00 & 0.00 \\
$\mathrm{LM}(4)$ & 0.00 & 0.33 & 0.00 & 0.98 & 0.00 & 0.01 \\
\hline \hline
\end{tabular}

Note: We set a dummy variable to control for the outliers in France (2000:2) and Italy (1996:1) which are due to the conversion of inflation expectations from qualitative into quantitative data. The p-values, which have been calculated using Newey-West standard errors to correct for overlapping forecast errors, are reported in brackets. The last two rows report p-values for an LM test for the null hypothesis of no autocorrelation up to the second and fourth lag.

Table 1: Unbiasedness of expectations

A further necessary condition for rational expectations is the efficiency of expectations which implies that no piece of information known at time $t-2$ or earlier can be used to explain the forecast error. A first indication for the inefficiency of expectations is given by the p-values of the serial correlation LM-test in table 1, which indicate that - except for Italy and France - the residuals are not free of autocorrelation. ${ }^{6}$ Autocorrelation in the forecast error implies that a shock to the inflation rate or to some other economic variable was not taken into account when the inflation forecast was made and that the same mistake was repeated in subsequent periods. In other words, efficiency of expectations requires that the forecast could not have been improved by adding additional information. In order to test for this, the forecast error is regressed on a number of exogenous variables that are known at time $t-2$ and that are possibly relevant when forecasting inflation. ${ }^{7}$ Table

\footnotetext{
${ }^{6}$ As the forecast horizon does not correspond to the frequency of the survey, shocks to the inflation rate can not be taken into account until the second period after the forecast and the same error may be repeated again. Thus, autocorrelation of order one in the error constitutes no irrationality.

${ }^{7}$ Our proceeding basically follows Roberts (1997) who introduced as potentially omitted variables the output gap as a measure of overall economic activity (see section 3.2 for a definition), the inflation rate to capture the persistence of inflation, and the three-month interest rate as an indicator for the stance of monetary policy. Since unit root tests indicated that the interest rates are non-stationary, we used first differences. In addition to that, we included real unit labor costs (see section 3.2 for a definition) and lagged terms of the forecast error. The explanatory power of each group of variables (which comprises four lags of the variable under consideration) was tested separately. The forecast error, real unit labor cost and the output gap enter the regression only from $t-3$ on, for reasons of overlapping forecast errors and because we assume a publication lag of one quarter.
} 
2 reports p-values related to $\chi^{2}$-statistics of a Wald test of the null hypothesis that the coefficients on the aforementioned lags of these regressors are jointly equal to zero. In the Euro zone, France, Germany, Italy and the UK lagged values of the forecast error can explain the movement of the forecast error at the five percent level, which is a hint that survey respondents seem to be sluggish when correcting their expectations after having recognized the last forecast error. Also past inflation rates are of explanatory use in all countries. This means that respondents underestimate the inertia of the inflation rate. In none of the countries except France the output gap has a significant influence, indicating that the respondents seem to take it into account when forming their expectations. By contrast, real unit labor costs seem to be omitted in the Euro zone, France, and the US. The three-month interest rate helps explain the forecast error in Germany, Italy, UK and the US. ${ }^{8}$

\begin{tabular}{l|ccccc}
\hline \hline Country & $\begin{array}{c}\text { Error } \\
\text { lags } 3 \text { to } 6\end{array}$ & $\begin{array}{c}\text { Inflation } \\
\text { lags } 2 \text { to } 5\end{array}$ & $\begin{array}{c}\text { Output gap } \\
\text { lags } 3 \text { to } 6\end{array}$ & $\begin{array}{c}\text { RULC } \\
\text { lags } 3 \text { to } 6\end{array}$ & $\begin{array}{c}\text { 3M Rate } \\
\text { lags 2 to 5 }\end{array}$ \\
\hline Euro zone & 0.00 & 0.00 & 0.11 & 0.04 & 0.17 \\
France & 0.00 & 0.00 & 0.00 & 0.00 & 0.43 \\
Germany & 0.03 & 0.01 & 0.60 & 0.07 & 0.00 \\
Italy & 0.00 & 0.00 & 0.16 & 0.08 & 0.02 \\
UK & 0.04 & 0.00 & 0.35 & 0.22 & 0.00 \\
US & 0.86 & 0.00 & 0.21 & 0.03 & 0.04 \\
\hline \hline
\end{tabular}

Note: Dummy variables are set like before. The table shows p-values for a heteroscedasticity and autocorrelation consistent (HAC) Wald-test on joint significance of each group of lagged variables (Error $=$ forecast error, RULC $=$ real unit labor cost, 3M Rate $=$ three-month nominal interest rate).

Table 2: Efficiency tests

\subsection{Measures for Real Marginal Costs}

There has been an extensive discussion in the literature about the correct proxy for real marginal costs (see for example Galí and Gertler, 1999, Galí, Gertler, and López-Salido, 2001 and Sbordone, 2005). There are basically two candidates that are considered: real unit labor costs and the output gap.

\footnotetext{
${ }^{8}$ Roberts (1997) and the studies cited there also find no support of the efficiency hypothesis for the US. Adam and Padula (2003) come to the same conclusion. For the Euro zone Forsells and Kenny (2002) who investigated qualitative inflation expectations from the European Commission's Consumer Survey also find that expectation were not efficient during the nineties.
} 
The hypothesis that real unit labor costs is a good proxy for real marginal costs can be justified by the assumption that the production technology is Cobb-Douglas and that capital is constant over time. Real marginal costs are then defined as the ratio of real wages to the marginal product of labor

$$
M C_{t}=\frac{1}{\alpha} \frac{W_{t} N_{t}}{P_{t} Y_{t}}
$$

where $\alpha$ is the labor elasticity of production, $W_{t}$ the nominal wage rate, $N_{t}$ employment, $P_{t}$ the price level, and $Y_{t}$ aggregate output. The second term on the right-hand-side is typically referred to as the labor income share or real unit labor costs. Log-linearizing equation (13) around the steady state gives

$$
m c_{t}=w_{t}+n_{t}-p_{t}-y_{t}
$$

where lower case-letters denote the percentage deviation of a variable around its steady state. Thus, under the assumption that $\alpha$ is constant over time, equation (14) shows that real marginal costs and real unit labor costs move in a one-to-one relation around their steady state.

While real unit labor costs are a direct measure of a firm's real marginal costs, it can be shown that under certain conditions the output gap is a close proxy. We will not go into the details of the derivation of this relationship because it has been well documented in standard textbooks on monetary economics (see for example Walsh, 2003, chapter 5.4). The idea is that after combining the households' labor supply decision (real wage equals the marginal rate of substitution between consumption and labor) with the firms' price-setting condition (price equals a mark-up over nominal marginal costs), an expression for the output level under both flexible and rigid prices can be derived. Under the assumption that labor market frictions exist but do not vary over time, real marginal costs are then a linear function of the output gap $x_{t}$

$$
m c_{t}=(\sigma+\eta)\left(y_{t}-y_{t}^{\text {flex }}\right)=(\sigma+\eta) x_{t}
$$

where $1 / \sigma$ is the intertemporal elasticity of substitution in consumption, $\eta$ the elasticity of marginal disutility with respect to labor supply, and $y_{t}^{\text {flex }}$ the $\log$ of the level of output that would prevail if prices were perfectly flexible (i.e. $\theta=0$ ). The HNKPC then becomes

$$
\pi_{t}=\gamma_{f} \bar{F}_{t}\left[\pi_{t+1}\right]+\gamma_{b} \pi_{t-1}+\lambda^{\prime} x_{t}+\varepsilon_{t}
$$

where $\lambda^{\prime}=\lambda(\sigma+\eta)$.

In our empirical analysis we consider both types of measures for real marginal costs. Specifically we use 

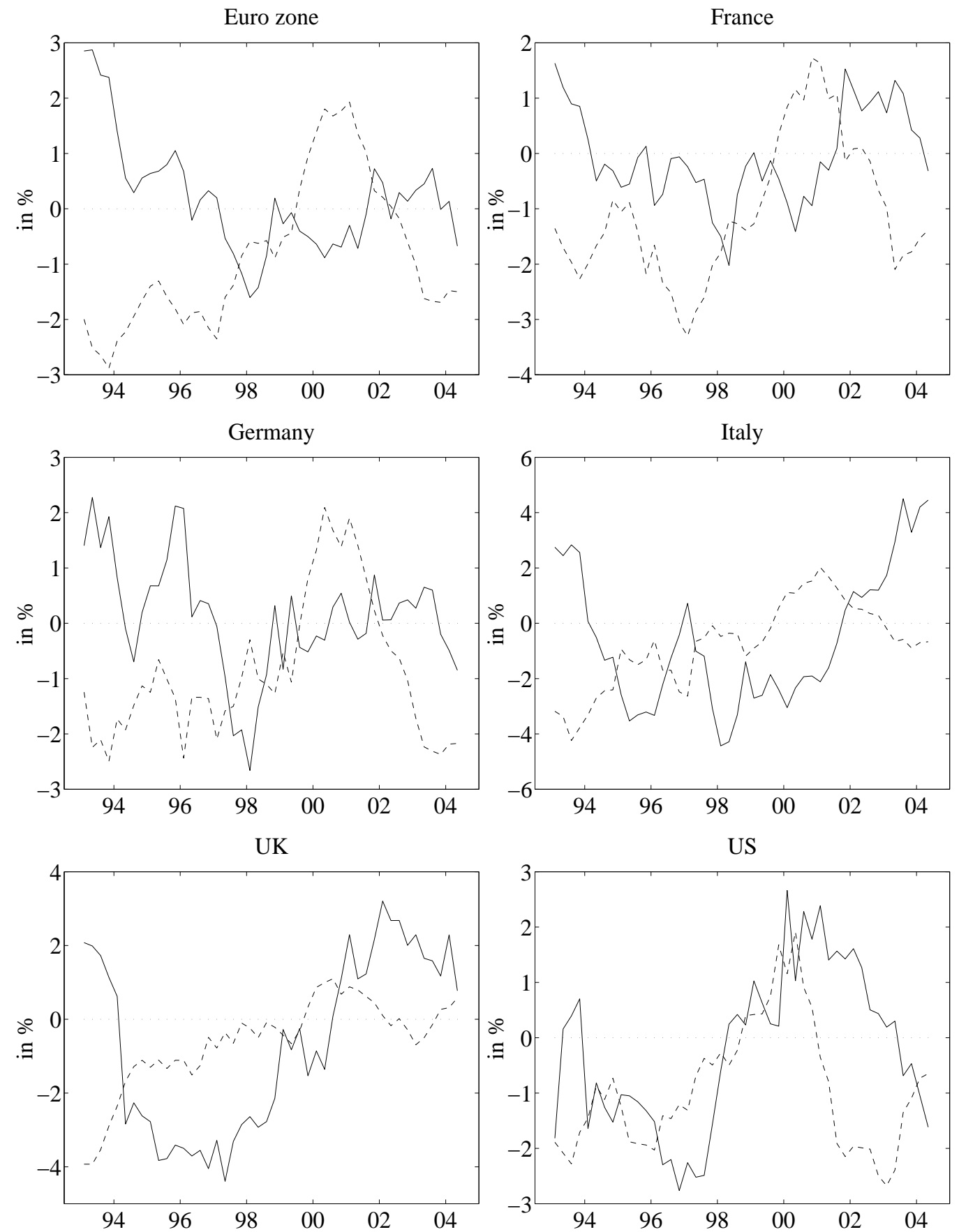

Figure 2: GAP (dashed line) and RULC (continuous line) 
- the deviation of the logarithm of CPI-deflated unit labor costs (of the total economy) ${ }^{9}$ from a linear trend (over the period 1990:1-2004:3): RULC;

- and the OECD output gap (as published in the OECD Economic Outlook, Vol. 2004/2, No. 76): ${ }^{10}$ GAP.

For each of the countries in our study figure 2 shows both measures in a single graph.

\section{Empirical Results}

\subsection{Estimations}

We begin by presenting estimates for the pure forward-looking New Keynesian Phillips curve which can be derived as a special case from the HNKPC by setting $\omega=0$ (see table 3 ). In the pure forward-looking case the estimated parameter of inflation expectations is equal to the discount factor $\beta$. Irrespective of the model specification the $\beta$ 's are all statistically significant and in the neighborhood of one. For all countries except for the UK and the US (and Italy at the 10\% level), Wald tests can not reject the null hypothesis that $\beta$ equals one. However, the estimated values of $\beta$ are smaller than one in those countries. Interestingly, Italy, the UK and the US are the three countries for which the Ifo WES inflation expectations turned out to be biased (see section 3.1). Concerning the slope coefficient $\lambda$ our results are to some extent in line with those obtained by Galí, Gertler, and López-Salido (2001) who used a rational expectations-GMM approach. While some of the estimated $\lambda$ 's of the RULC model (Euro zone, France and Germany) are positive and significant, the rest of the countries show no significant effect. The $\lambda$ of the output gap model is positive and significant only for the UK. For all other countries (except for France) it turns out to be negative, but the influence on inflation is insignificant. These results are perfectly in line with the cross correlations between inflation and RULC on the one hand, and inflation and the output gap on the other hand (see figure 3). For $k=0$ (that is, contemporaneous correlation) $\lambda$ is positive and significant only in

\footnotetext{
${ }^{9}$ Unit labor costs of the total economy are taken from the OECD database. Italian unit labor costs are only available for the business sector (which is defined as total economy minus public sector).

${ }^{10}$ Alternative measures of the output gap, such as a Hodrick-Prescott-filtered GDP series or the rate of capacity utilization, gave qualitatively similar results and are available from the authors upon request.
} 
those cases where correlations in figure 2 are positive as well. In many cases, however, the estimations of the pure forward-looking New Keynesian Phillips curve produce residuals which are strongly auto-correlated which indicates that some important explanatory variables are missing.

\begin{tabular}{|c|c|c|c|c|c|c|}
\hline & \multicolumn{3}{|c|}{$\overline{\mathrm{RULC}}$} & \multicolumn{3}{|c|}{ GAP } \\
\hline & $\beta$ & $\lambda$ & $\beta=1$ & $\beta$ & $\lambda^{\prime}$ & $\beta=1$ \\
\hline \multirow[t]{2}{*}{ Euro zone } & 1.03 & 0.16 & \multirow[t]{2}{*}{0.39} & 1.02 & -0.08 & \multirow[t]{2}{*}{0.72} \\
\hline & {$[0.00]$} & {$[0.00]$} & & {$[0.00]$} & {$[0.25]$} & \\
\hline \multirow[t]{2}{*}{ France } & 0.97 & 0.08 & \multirow[t]{2}{*}{0.22} & 1.00 & 0.03 & \multirow[t]{2}{*}{0.89} \\
\hline & {$[0.00]$} & {$[0.03]$} & & {$[0.00]$} & {$[0.24]$} & \\
\hline \multirow[t]{2}{*}{ Germany } & 1.07 & 0.36 & \multirow[t]{2}{*}{0.42} & 1.05 & -0.09 & \multirow[t]{2}{*}{0.71} \\
\hline & {$[0.00]$} & {$[0.02]$} & & {$[0.00]$} & {$[0.62]$} & \\
\hline \multirow[t]{2}{*}{ Italy } & 0.91 & 0.02 & \multirow[t]{2}{*}{0.06} & 0.89 & -0.07 & \multirow[t]{2}{*}{0.06} \\
\hline & {$[0.00]$} & {$[0.62]$} & & {$[0.00]$} & [0.41] & \\
\hline \multirow[t]{2}{*}{ UK } & 0.85 & -0.00 & \multirow[t]{2}{*}{0.00} & 0.87 & 0.11 & \multirow[t]{2}{*}{0.00} \\
\hline & {$[0.00]$} & [0.99] & & {$[0.00]$} & {$[0.01]$} & \\
\hline \multirow[t]{2}{*}{ US } & 0.85 & 0.07 & \multirow[t]{2}{*}{0.00} & 0.82 & -0.06 & \multirow[t]{2}{*}{0.00} \\
\hline & {$[0.00]$} & {$[0.16]$} & & {$[0.00]$} & [0.13] & \\
\hline
\end{tabular}

Notes: Numbers in brackets are p-values which were calculated using HAC Newey-West standard errors. For France and Italy we set a dummy variable in 2000:2 and 1996:1, respectively (see section 3.1). For the test on $\beta=1$ we show p-values that are the result of a HAC Wald-test.

Table 3: Estimation results for the forward-looking Phillips curve

We therefore turn to the estimation of the HNKPC which explicitly allows lagged inflation to have additional explanatory power for current inflation. Table 4 reveals that in all of our estimations of the HNKPC the coefficients for both subjective inflation expectations and lagged inflation are positive and significant. For most countries the point estimates of $\gamma_{b}$ turn out to be higher in the output gap model, whereas the $\gamma_{f}$ 's are somewhat lower. Looking at the individual countries, we can distinguish between three groups. In Germany and Italy the degree of backwardness is relatively high. Irrespective of the measure for marginal costs, $\gamma_{b}$ exceeds $\gamma_{f}$. In France the opposite is true. The estimated $\gamma_{f}$ 's are higher than the $\gamma_{b}$ 's, implying that French firms are more forward-looking than their German or Italian competitors. In the Euro zone as a whole, the US and - to some extent - the UK optimizing firms and rule-of-thumb price setters are more or less balanced.

The sign and significance of the measure for real marginal costs crucially depend on the empirical specification of the HNKPC and differ from the results obtained from the estimation of the purely forward-looking Phillips curve. The most striking result is that the output gap becomes an important 
$\operatorname{corr}\left(\pi_{t}, r u l c_{t+k}\right)$
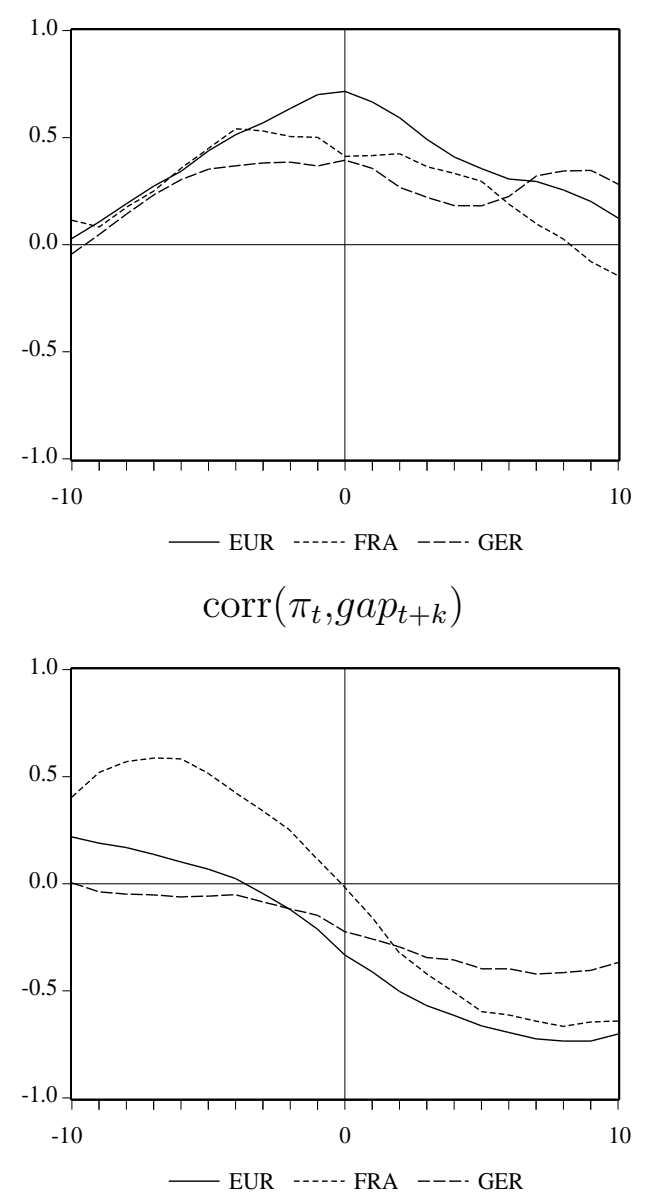

$\operatorname{corr}\left(\pi_{t}\right.$, rulc $\left._{t+k}\right)$
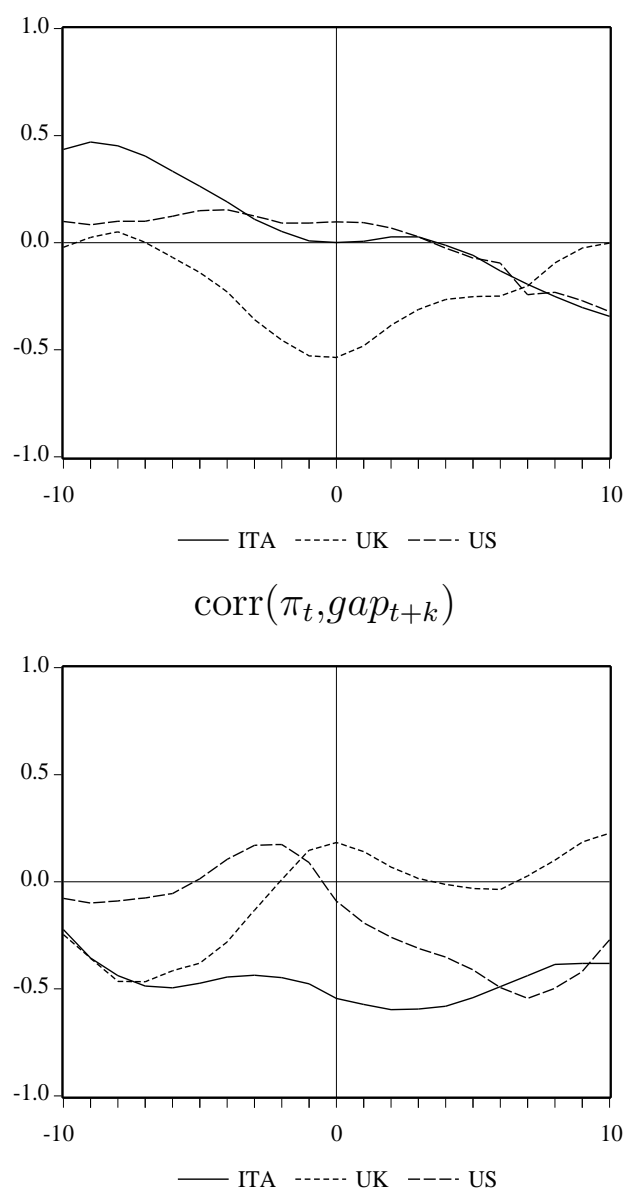

Note: The correlation coefficient is depicted on the vertical axis, and $k$ on the horizontal axis.

Figure 3: Cross correlograms

explanatory variable for inflation in France, Italy and - as in the forwardlooking version - the UK, which is astonishing, given the low and mostly negative contemporaneous correlation between the output gap and inflation (see figure 3). From an econometric point of view the significant output gap coefficients can be explained by the high correlation of the output gap with the unexplained part of a regression of inflation on lagged and expected inflation. When RULC are used as a measure for marginal costs the results are more or less in line with those for the purely forward-looking Phillips curve. The $\lambda$ 's for the Euro zone and France remain positive and significant whereas $\lambda$ for Germany becomes insignificant. Our results indicate that the impact of marginal cost on inflation in the US is best captured by RULC 
as we find a positive and significant effect on inflation. These results are roughly in line with the cross correlations we present in the upper part of figure 3 .

A necessary condition for the dynamic process to be stable is that the sum of $\gamma_{f}$ and $\gamma_{b}$ does not exceed one. To be sure that the process is not exploding, we also estimate a restricted version of the HNKPC where $\gamma_{f}+\gamma_{b}=1$. Table 5 shows that the estimates of $\gamma_{f}$ are still highly significant in every country. For the Euro zone, France, Germany, Italy and the UK the imposed restriction leaves the estimates of both, $\gamma_{f}$ and $\lambda / \lambda^{\prime}$ more or less unchanged. In the US, by contrast, $\gamma_{f}$ becomes significantly smaller than in the unrestricted estimation. Moreover, the impact of RULC on inflation turns out to become insignificant, whereas the output gap yields positive and significant estimates now. A further hint that a restricted regression may not be appropriate in the case of the US comes from a Wald test applied to the unrestricted regression which rejects the restriction $\gamma_{f}+\gamma_{b}=1$ at the $1 \%$ level.

\subsection{Robustness of the Estimates}

In this section we want to investigate whether our estimates from tables 3 to 5 are robust with respect to OLS assumptions. One problem that may arise is that the estimations in the last section suffer from endogeneity of the regressors. In particular we may suspect that the expectational variable $\bar{F}_{t} \pi_{t+2}$ is caused by the current inflation rate, a problem which is often addressed as simultaneity. Moreover, the OLS estimations of the HNKPC may suffer from autocorrelation in the residuals. In this case the lagged endogenous variable $\pi_{t-1}$ may be correlated with the error term of the regression equation. However, a lagged endogenous variable is present only in the hybrid version of the Phillips Curve. In a purely forward looking framework it should be sufficient to perform a Newey-West adjustment of the regression standard errors for a correct inference in the presence of autocorrelated residuals.

We check the robustness of OLS estimates by estimating the hybrid and the forward-looking version again by using instrumental variables methods. Specifically, we run a two-stage least squares (TSLS) regression where we instrument for $\bar{F}_{t} \pi_{t+2}$ when estimating both types of Phillips curves. In the hybrid version we additionally instrument for $\pi_{t-1}$, even though autocorrelation in the residuals arises mainly when estimating the purely forwardlooking Phillips curve. We also do a Newey-West adjustment of the variancecovariance matrices of the estimators to obtain heteroscedasticity and autocorrelation robust standard errors.

We consider up to four lagged terms as instruments of $\bar{F}_{t} \pi_{t+2}$ as they 


\begin{tabular}{l|ccc|ccr}
\hline \hline & \multicolumn{3}{|c}{ RULC } & \multicolumn{3}{c}{ GAP } \\
& $\gamma_{f}$ & $\gamma_{b}$ & $\lambda$ & $\gamma_{f}$ & $\gamma_{b}$ & \multicolumn{1}{c}{$\lambda^{\prime}$} \\
\hline \multirow{3}{*}{ Euro zone } & 0.55 & 0.47 & 0.07 & 0.51 & 0.52 & -0.00 \\
& {$[0.00]$} & {$[0.00]$} & {$[0.04]$} & {$[0.00]$} & {$[0.00]$} & {$[0.94]$} \\
\cline { 2 - 7 } France & 0.78 & 0.21 & 0.06 & 0.76 & 0.25 & 0.04 \\
Germany & {$[0.00]$} & {$[0.00]$} & {$[0.03]$} & {$[0.00]$} & {$[0.00]$} & {$[0.01]$} \\
\cline { 2 - 7 } & 0.29 & 0.74 & 0.08 & 0.28 & 0.78 & 0.04 \\
Italy & {$[0.00]$} & {$[0.00]$} & {$[0.27]$} & {$[0.00]$} & {$[0.00]$} & {$[0.30]$} \\
\cline { 2 - 7 } & 0.25 & 0.72 & -0.01 & 0.26 & 0.74 & 0.05 \\
\multirow{4}{*}{ UK } & {$[0.00]$} & {$[0.00]$} & {$[0.47]$} & {$[0.00]$} & {$[0.00]$} & {$[0.00]$} \\
\cline { 2 - 7 } & 0.49 & 0.43 & -0.01 & 0.52 & 0.42 & 0.10 \\
& {$[0.00]$} & {$[0.00]$} & {$[0.83]$} & {$[0.00]$} & {$[0.00]$} & {$[0.00]$} \\
\cline { 2 - 7 } & 0.46 & 0.46 & 0.04 & 0.44 & 0.48 & 0.01 \\
& {$[0.00]$} & {$[0.00]$} & {$[0.07]$} & {$[0.00]$} & {$[0.00]$} & {$[0.70]$} \\
\hline \hline
\end{tabular}

Notes: See table 3.

Table 4: Estimation results for the hybrid Phillips curve

\begin{tabular}{l|cc|cc}
\hline \hline \multirow{4}{*}{ Euro zone } & \multicolumn{2}{|c}{ RULC } & \multicolumn{2}{c}{ GAP } \\
& $\gamma_{f}$ & \multicolumn{1}{c}{$\lambda$} & $\gamma_{f}$ & $\lambda^{\prime}$ \\
\hline \multirow{4}{*}{ France } & 0.52 & 0.08 & 0.49 & -0.02 \\
& {$[0.00]$} & {$[0.00]$} & {$[0.00]$} & {$[0.32]$} \\
\cline { 2 - 5 } Germany & 0.78 & 0.05 & 0.76 & 0.03 \\
& {$[0.00]$} & {$[0.05]$} & {$[0.00]$} & {$[0.04]$} \\
\cline { 2 - 5 } Italy & 0.26 & 0.09 & 0.22 & 0.00 \\
& {$[0.00]$} & {$[0.24]$} & {$[0.00]$} & {$[0.94]$} \\
\cline { 2 - 5 } UK & 0.25 & -0.01 & 0.26 & 0.06 \\
& {$[0.00]$} & {$[0.70]$} & {$[0.00]$} & {$[0.00]$} \\
\cline { 2 - 5 } US & 0.44 & 0.02 & 0.48 & 0.14 \\
& {$[0.00]$} & {$[0.42]$} & {$[0.00]$} & {$[0.00]$} \\
\cline { 2 - 5 } & 0.35 & 0.05 & 0.36 & 0.08 \\
\hline \hline
\end{tabular}

Notes: See table 3.

Table 5: Estimation results for the hybrid Phillips curve when $\gamma_{f}+\gamma_{b}=1$ 
should be exogenous to $\pi_{t}$. The reason is that $\pi_{t}$ is not part of the information set at time $t-1$. We also use four lags of either RULC or GAP as instruments as these are the driving variables in the inflation process. Four lags should be sufficient to account for the dynamics in the economy.

In order to test whether these instrumental variable estimations suffer from weak instruments we present, in a first step, the $R^{2}$ of the first stage regressions as well as the partial $R^{2}$ as proposed by Shea (1997). The latter measures the explanatory power of the instruments with respect to the portion of the endogenous explanatory variable that is orthogonal to the other explanatory variables of the estimation equation. Having argued before that instruments are exogenous, we also find that they can explain the variation in the endogenous explanatory variables as first-stage $R^{2} \mathrm{~s}$ as well as partial $R^{2}$ s are reasonably high (see table 6 ).

\begin{tabular}{ll|cccccc}
\hline \hline & $\begin{array}{c}\text { Euro } \\
\text { zone }\end{array}$ & France & $\begin{array}{c}\text { Ger } \\
\text {-many }\end{array}$ & Italy & UK & US \\
\cline { 3 - 8 } & & \multicolumn{6}{c}{ RULC } \\
\hline $\bar{F}_{t} \pi_{t+2}$ & $1^{\text {st }}$ stage $R^{2}$ & 0.71 & 0.73 & 0.45 & 0.84 & 0.60 & 0.51 \\
& part. $R^{2}$ & 0.39 & 0.23 & 0.21 & 0.32 & 0.33 & 0.12 \\
\hline$\pi_{t-1}$ & $1^{\text {st }}$ stage $R^{2}$ & 0.93 & 0.86 & 0.73 & 0.64 & 0.84 & 0.86 \\
& part. $R^{2}$ & 0.39 & 0.23 & 0.21 & 0.30 & 0.35 & 0.12 \\
\hline & & \multicolumn{6}{|c}{ GAP } \\
\hline $\bar{F}_{t} \pi_{t+2}$ & $1^{\text {st }}$ stage $R^{2}$ & 0.75 & 0.68 & 0.47 & 0.84 & 0.59 & 0.59 \\
& part. $R^{2}$ & 0.32 & 0.21 & 0.29 & 0.36 & 0.33 & 0.37 \\
\hline$\pi_{t-1}$ & $1^{\text {st }}$ stage $R^{2}$ & 0.91 & 0.82 & 0.59 & 0.59 & 0.88 & 0.85 \\
& part. $R^{2}$ & 0.25 & 0.23 & 0.30 & 0.30 & 0.37 & 0.31 \\
\hline \hline
\end{tabular}

Table 6: First stage $R^{2}$ and partial $R^{2}$

In a second step we present the results of the TSLS regressions in tables 7 to 9 . Provided that the instruments are valid, it is possible to test whether one of the regressors is endogenous. The OLS estimator is consistent and efficient only if there is no endogenous regressor. The TSLS estimator is not efficient, but consistent even in the case of endogeneity. Hausman (1978) proposed a test which compares the coefficient vectors $\hat{\beta}_{I V}$ and $\hat{\beta}_{O L S}$ from both regressions. ${ }^{11}$ If they are not systematically different, one should rely on the results of the OLS regression and conclude that there is no problem of

\footnotetext{
${ }^{11}$ The test statistic is calculated as $H=\left(\hat{\beta}_{I V}-\hat{\beta}_{O L S}\right)^{\prime}\left(\hat{V}\left(\hat{\beta}_{I V}\right)-\hat{V}\left(\hat{\beta}_{O L S}\right)\right)^{-1}\left(\hat{\beta}_{I V}-\right.$ $\left.\hat{\beta}_{O L S}\right)$, where $\hat{V}$ is the variance-covariance matrix. It has a $\chi^{2}$ distribution with degrees of freedom equal to the number of estimated coefficients.
} 
endogenous regressors. ${ }^{12}$ In tables 7 to 9 we show the p-values for a Hausman test $\left(H_{0}: \hat{\beta}_{O L S}\right.$ is consistent and efficient) in the columns which are labeled with $H$.

\begin{tabular}{l|ccc|rrr}
\hline \hline & \multicolumn{3}{|c}{ RULC } & \multicolumn{3}{c}{ GAP } \\
& $\beta$ & $\lambda$ & $\mathrm{H}$ & $\beta$ & \multicolumn{1}{c}{$\lambda^{\prime}$} & \multicolumn{1}{c}{$\mathrm{H}$} \\
\hline \multirow{3}{*}{ Euro zone } & 1.03 & 0.16 & 0.08 & 1.03 & -0.07 & 0.06 \\
& {$[0.00]$} & {$[0.01]$} & & {$[0.00]$} & {$[0.30]$} & \\
\cline { 2 - 8 } France & 0.94 & 0.14 & 0.38 & 0.92 & -0.04 & 0.44 \\
& {$[0.00]$} & {$[0.03]$} & & {$[0.00]$} & {$[0.50]$} & \\
\cline { 2 - 8 } Germany & 1.14 & 0.34 & 0.01 & 1.13 & -0.03 & 0.09 \\
& {$[0.00]$} & {$[0.02]$} & & {$[0.00]$} & {$[0.87]$} & \\
\cline { 2 - 8 } Italy & 0.97 & -0.05 & 0.23 & 0.96 & -0.13 & 0.10 \\
\multirow{4}{*}{ UK } & {$[0.00]$} & {$[0.68]$} & & {$[0.00]$} & {$[0.44]$} & \\
\cline { 2 - 8 } & 0.86 & 0.01 & 0.02 & 0.89 & 0.12 & 0.01 \\
& {$[0.00]$} & {$[0.88]$} & & {$[0.00]$} & {$[0.00]$} & \\
\cline { 2 - 8 } & 0.86 & 0.08 & 0.01 & 0.84 & -0.05 & 0.02 \\
& {$[0.00]$} & {$[0.13]$} & & {$[0.00]$} & {$[0.19]$} & \\
\hline \hline
\end{tabular}

Notes: See table 3.

Table 7: IV (TSLS) estimation results for the forward-looking Phillips curve

Comparing the results in table 7 with those in table 3 shows that the estimated coefficients do not change substantially. Only in Germany the $\beta$ 's are somewhat higher, whereas in France the TSLS estimation leads to lower coefficients. In addition, the (in)significant OLS estimates for $\lambda$ all remain (in)significant when applying the TSLS procedure. Nevertheless, we calculate test statistics for the Hausman test which are significant at the 5\% level in three (two) cases when we use GAP (RULC) as a measure for real marginal costs. This may be due to the fact that we did apply the test to OLS and TSLS estimates that were not adjusted for heteroscedasticity and autocorrelation. As the latter is apparently a problem when estimating the purely forward-looking Phillips curve, also the application of the Hausman test may be problematic here because estimated variance-covariance matrices $\hat{V}$ may not be correct.

However, in case of the HNKPC the test indicates that we can rely on the OLS estimates. Turning to table 8, the TSLS estimates are close to those obtained in table 4 . This fact is reflected by the test statistic $H$

\footnotetext{
${ }^{12}$ Note that the distribution of the test statistic is only known for variance-covariance matrices of estimators that have not been adjusted for heteroscedasticity and autocorrelation. Therefore, we use the unadjusted variance-covariance matrices to calculate the test statistic. However, the p-values for the significance of the estimated parameters were calculated using Newey-West adjustment of the standard errors.
} 


\begin{tabular}{l|cccc|cccc}
\hline \hline & \multicolumn{4}{|c}{ RULC } & \multicolumn{5}{c}{ GAP } \\
& $\gamma_{f}$ & $\gamma_{b}$ & $\lambda$ & $\mathrm{H}$ & $\gamma_{f}$ & $\gamma_{b}$ & $\lambda^{\prime}$ & $\mathrm{H}$ \\
\hline \multirow{3}{*}{ Euro zone } & 0.57 & 0.45 & 0.07 & 0.73 & 0.51 & 0.52 & -0.00 & 0.91 \\
& {$[0.00]$} & {$[0.00]$} & {$[0.04]$} & & {$[0.00]$} & {$[0.00]$} & {$[0.91]$} & \\
\cline { 2 - 10 } France & 0.84 & 0.15 & 0.06 & 0.97 & 0.83 & 0.20 & 0.06 & 0.97 \\
& {$[0.00]$} & {$[0.21]$} & {$[0.10]$} & & {$[0.00]$} & {$[0.33]$} & {$[0.01]$} & \\
\cline { 2 - 10 } Germany & 0.15 & 0.86 & 0.04 & 0.64 & 0.06 & 0.96 & 0.04 & 0.28 \\
& {$[0.20]$} & {$[0.00]$} & {$[0.57]$} & & {$[0.63]$} & {$[0.00]$} & {$[0.36]$} & \\
\cline { 2 - 10 } Italy & 0.28 & 0.69 & -0.01 & 0.66 & 0.29 & 0.70 & 0.05 & 0.67 \\
\multirow{4}{*}{ UK } & {$[0.00]$} & {$[0.00]$} & {$[0.69]$} & & {$[0.00]$} & {$[0.00]$} & {$[0.00]$} & \\
\cline { 2 - 10 } & 0.54 & 0.38 & -0.00 & 0.84 & 0.54 & 0.40 & 0.10 & 0.99 \\
\cline { 2 - 9 } & {$[0.00]$} & {$[0.00]$} & {$[0.89]$} & & {$[0.00]$} & {$[0.00]$} & {$[0.00]$} & \\
\cline { 2 - 10 } & 0.47 & 0.45 & 0.04 & 0.62 & 0.44 & 0.48 & 0.01 & 0.82 \\
& {$[0.00]$} & {$[0.00]$} & {$[0.07]$} & & {$[0.00]$} & {$[0.00]$} & {$[0.76]$} & \\
\hline \hline
\end{tabular}

Notes: See table 3.

Table 8: IV (TSLS) estimation results for the hybrid Phillips curve

\begin{tabular}{l|ccc|ccc}
\hline \hline & \multicolumn{3}{|c}{ RULC } & \multicolumn{3}{c}{ GAP } \\
& $\gamma_{f}$ & $\lambda$ & $\mathrm{H}$ & $\gamma_{f}$ & $\lambda^{\prime}$ & $\mathrm{H}$ \\
\hline \multirow{3}{*}{ Euro zone } & 0.53 & 0.08 & 0.99 & 0.48 & -0.02 & 0.98 \\
& {$[0.00]$} & {$[0.00]$} & & {$[0.00]$} & {$[0.34]$} & \\
\cline { 2 - 8 } France & 0.83 & 0.05 & 0.94 & 0.80 & 0.03 & 0.99 \\
& {$[0.00]$} & {$[0.11]$} & & {$[0.00]$} & {$[0.07]$} & \\
\cline { 2 - 8 } Germany & 0.13 & 0.04 & 0.30 & 0.03 & 0.03 & 0.11 \\
& {$[0.05]$} & {$[0.57]$} & & {$[0.81]$} & {$[0.41]$} & \\
\cline { 2 - 8 } Italy & 0.25 & -0.01 & 0.99 & 0.28 & 0.06 & 0.57 \\
\multirow{3}{*}{ UK } & {$[0.01]$} & {$[0.74]$} & & {$[0.00]$} & {$[0.00]$} & \\
\cline { 2 - 8 } & 0.41 & 0.02 & 0.84 & 0.45 & 0.13 & 0.75 \\
US & {$[0.00]$} & {$[0.50]$} & & {$[0.00]$} & {$[0.00]$} & \\
\cline { 2 - 8 } & 0.19 & 0.02 & 0.07 & 0.28 & 0.08 & 0.22 \\
& {$[0.02]$} & {$[0.59]$} & & {$[0.00]$} & {$[0.04]$} & \\
\hline \hline
\end{tabular}

Notes: See table 3.

Table 9: IV (TSLS) estimation results for the hybrid Phillips curve when $\gamma_{f}+\gamma_{b}=1$ 
being insignificant. To some extent, France and Germany are an exception as French firms turn out to be even more forward-looking compared to the OLS estimates, while German firms are now highly backward-looking with $\gamma_{f}$ even becoming insignificant. Nevertheless, the Hausman test indicates that we should rely on the OLS estimates also in these cases. Similar results are obtained in table 9 where we estimated the restricted HNKPC with TSLS. Here, the US turns out to be more backward-looking compared to OLS results but this may again only reflect the fact that the restriction we set on the coefficients are not valid here. In general the TSLS estimates together with the Hausman test results indicate that the OLS procedure is superior to TSLS and yields reliable estimates for the Phillips curve.

\subsection{Stability}

A further issue that needs to be addressed is whether the estimated coefficients of the Phillips curve are stable over time. Figures 4 and 5 show the results of a CUSUM of squares test at the 1\% level. For both, the purely forward-looking Phillips curves and the HNKPC, the cumulated sum of squares of recursive residuals lie within the significance lines for Germany, Italy, the UK and the US, implying that the regression relationship is constant over time, irrespective of the chosen measure for real marginal cost. For the other countries, the cumulated sum of squares of recursive residuals temporarily crosses the significance lines, but then stays inside the thresholds again.
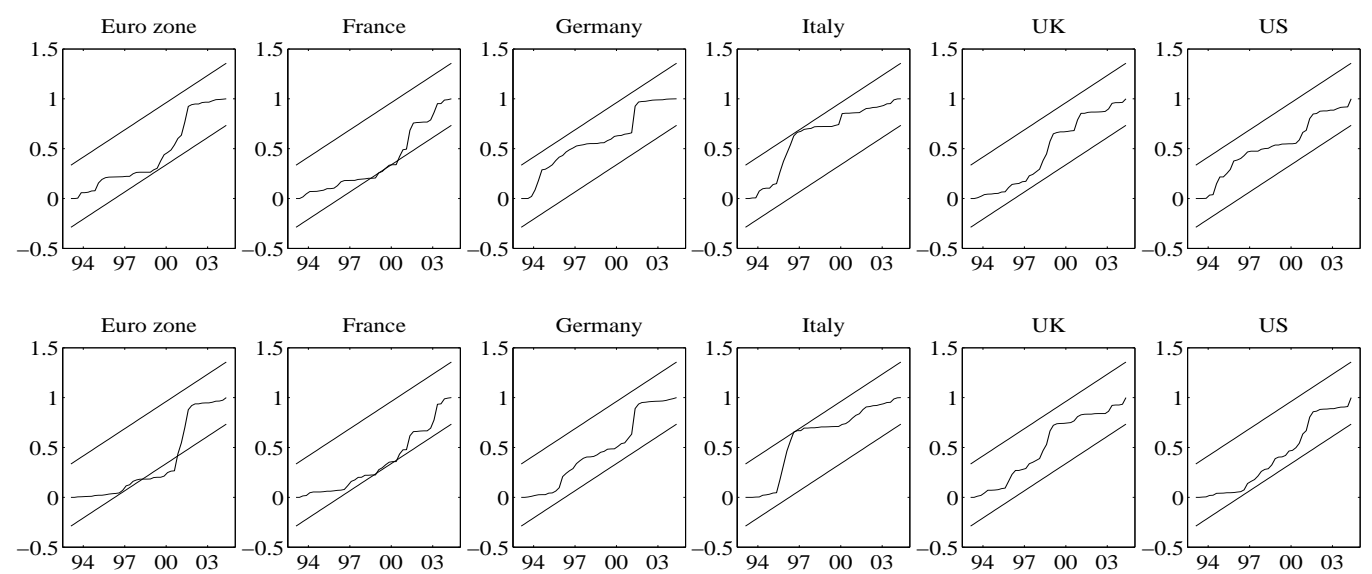

Figure 4: CUSUM of squares of the forward-looking Phillips curve: RULC (upper panel) and GAP (lower panel). 

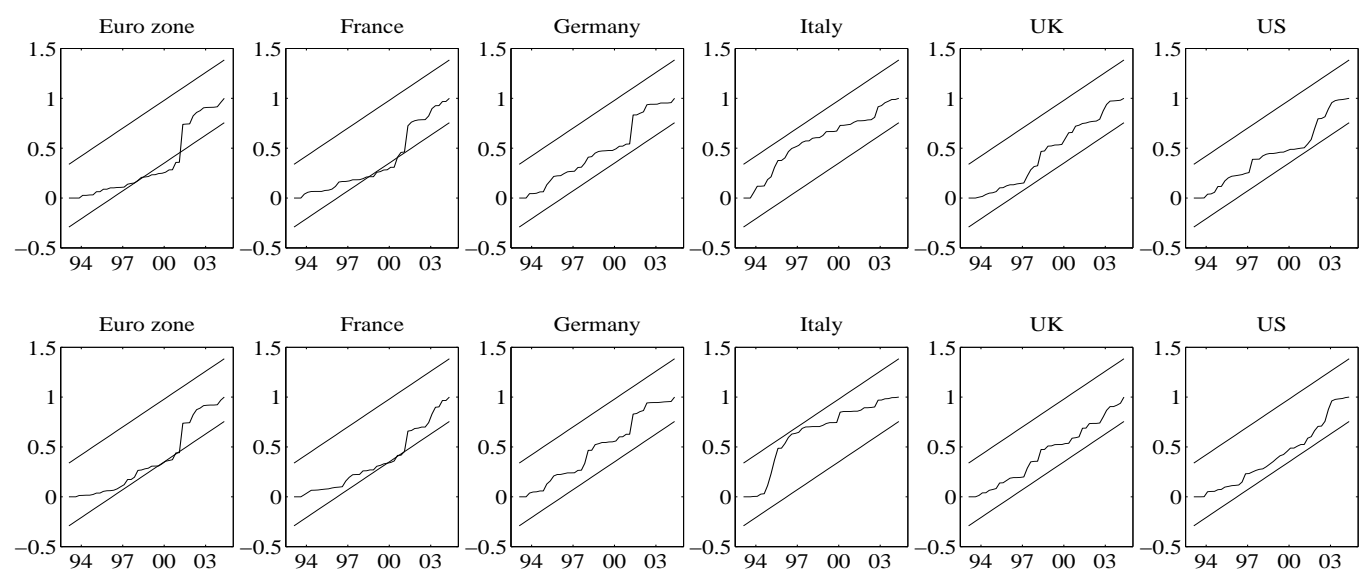

Figure 5: CUSUM of squares of HNKPC: RULC (upper panel) and GAP (lower panel).

\subsection{Summary of the Results and Comparison with other Studies}

In this section we want to compare our results with those obtained in other empirical studies. The direct use of measures for inflation expectations which naturally avoids any assumptions on the expectations formation process is much less popular. We only found five studies using either survey data or OECD forecasts for expectations which are summarized in table 10. The great majority of empirical work on the New Keynesian Phillips curve applies the rational expectations approach. Table 11 presents some of the most recent papers.

A great part of the discussion in most of the empirical work is concerned with the question about the correct proxy variable for real marginal costs. For the US Galí and Gertler (1999), Galí, Gertler, and López-Salido (2001) and Sbordone (2005) show that real unit labor costs empirically perform much better than the output gap. Above all, they find that slope of the Phillips curve becomes significantly negative. A notable exception is the paper of Jondeau and LeBihan (2006) who come to the conclusion that the output gap model is the preferred specification in Germany, Italy and the Euro zone. When survey data are used to measure inflation expectations, the results in favor of the output gap are more promising. Our paper shows that the slope of the Phillips curve is always positive and even significant in France, Italy and the UK. This finding is in line with all other survey data studies listed in table 10. 


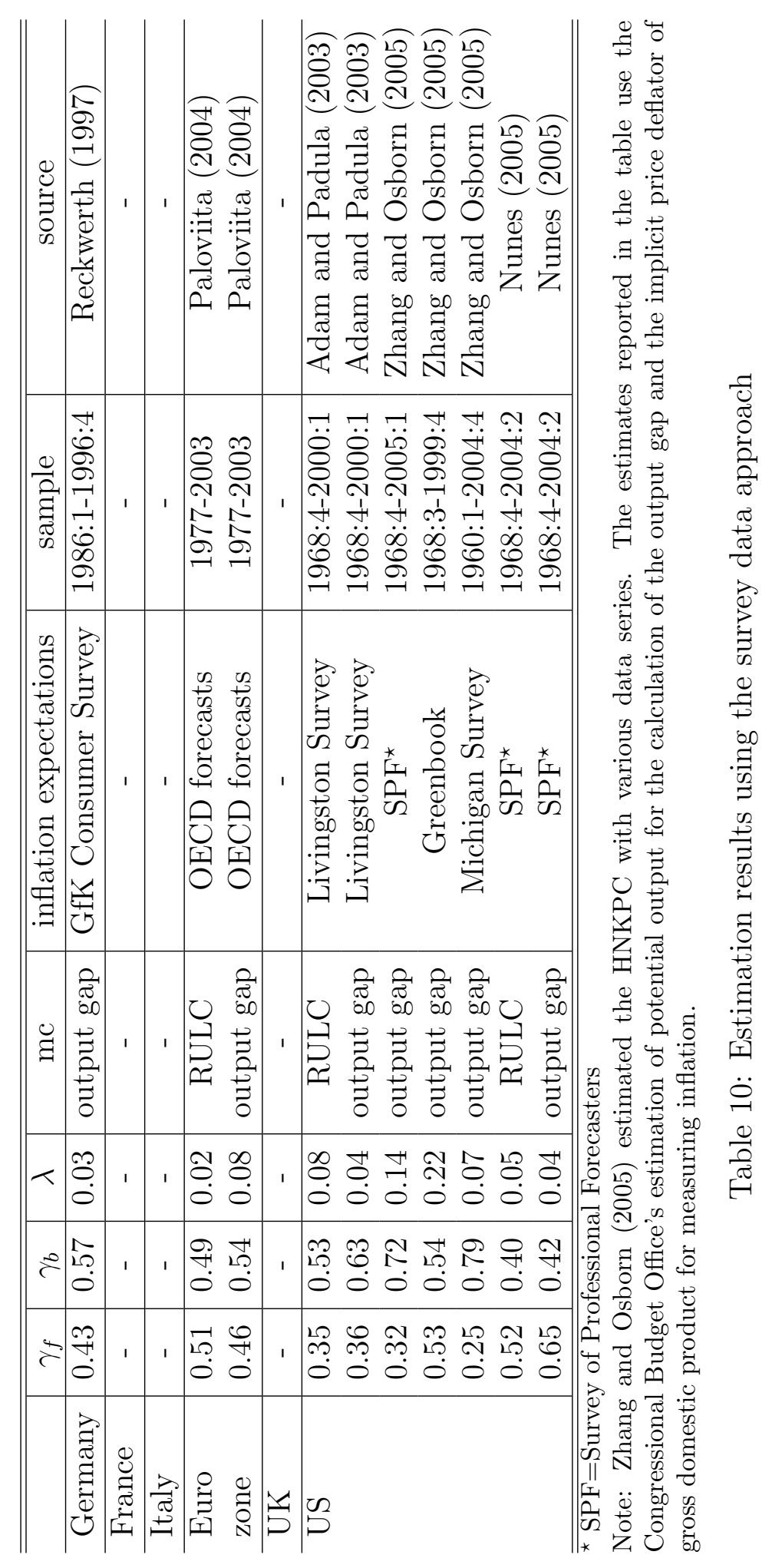




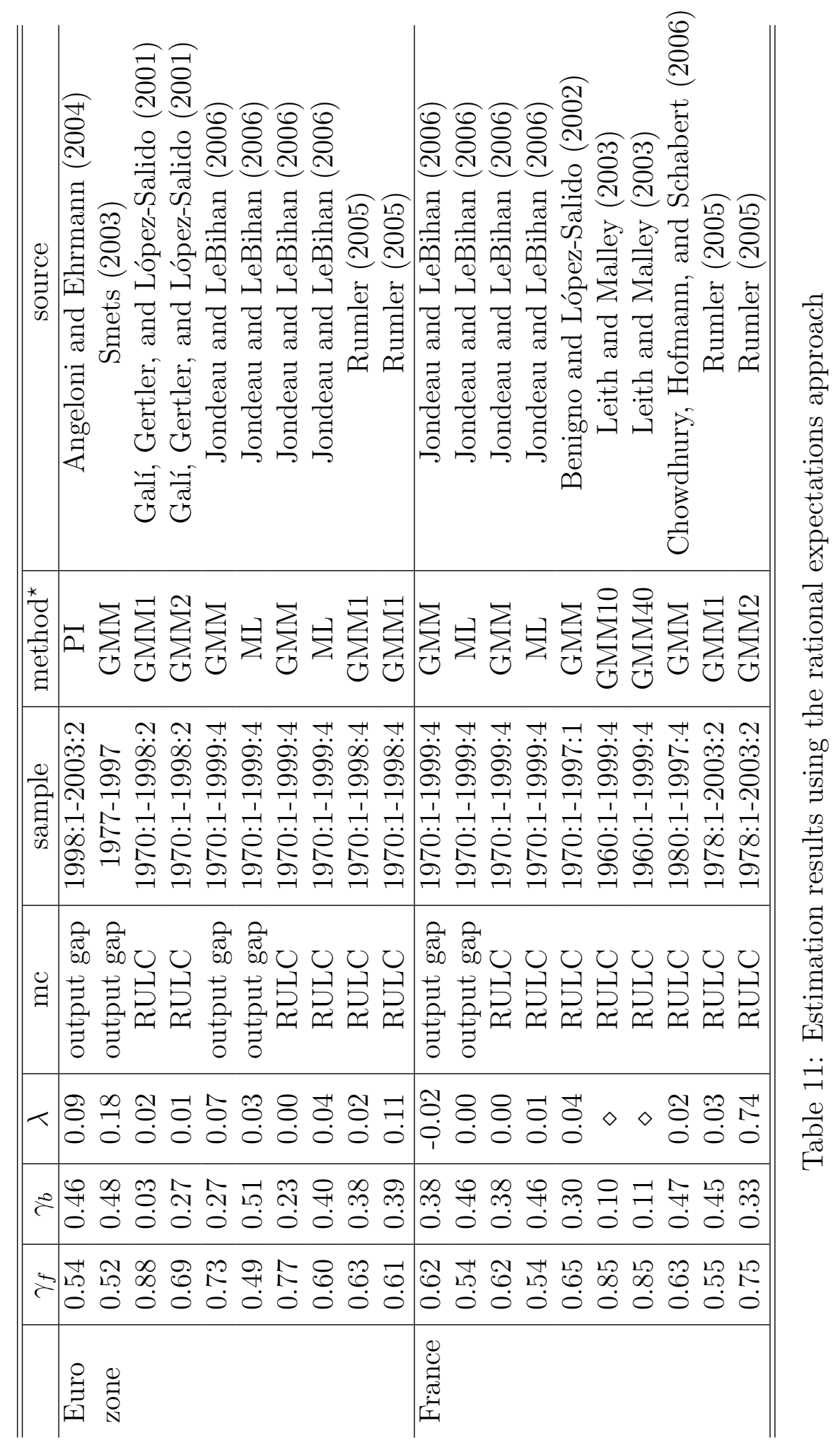




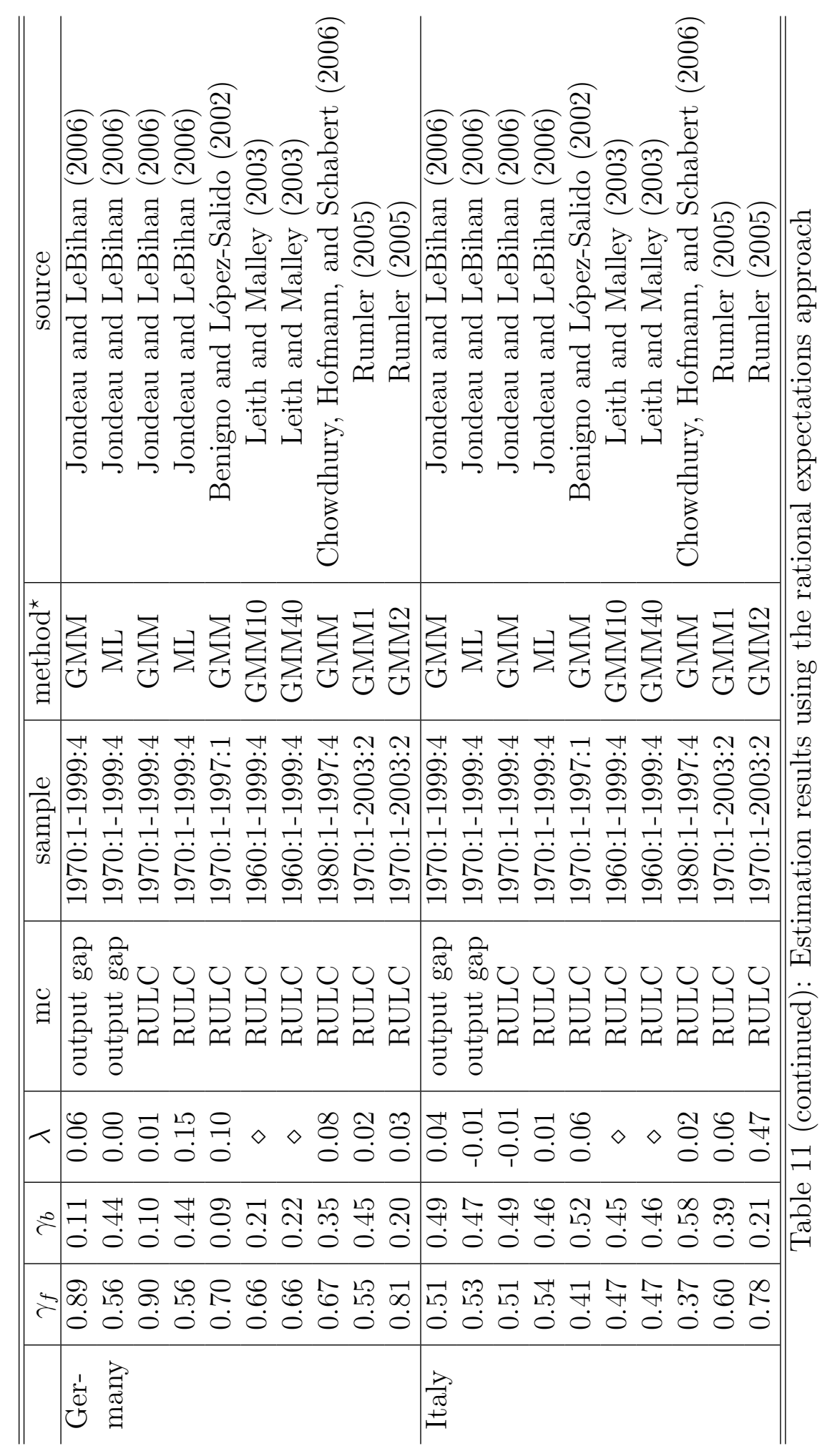




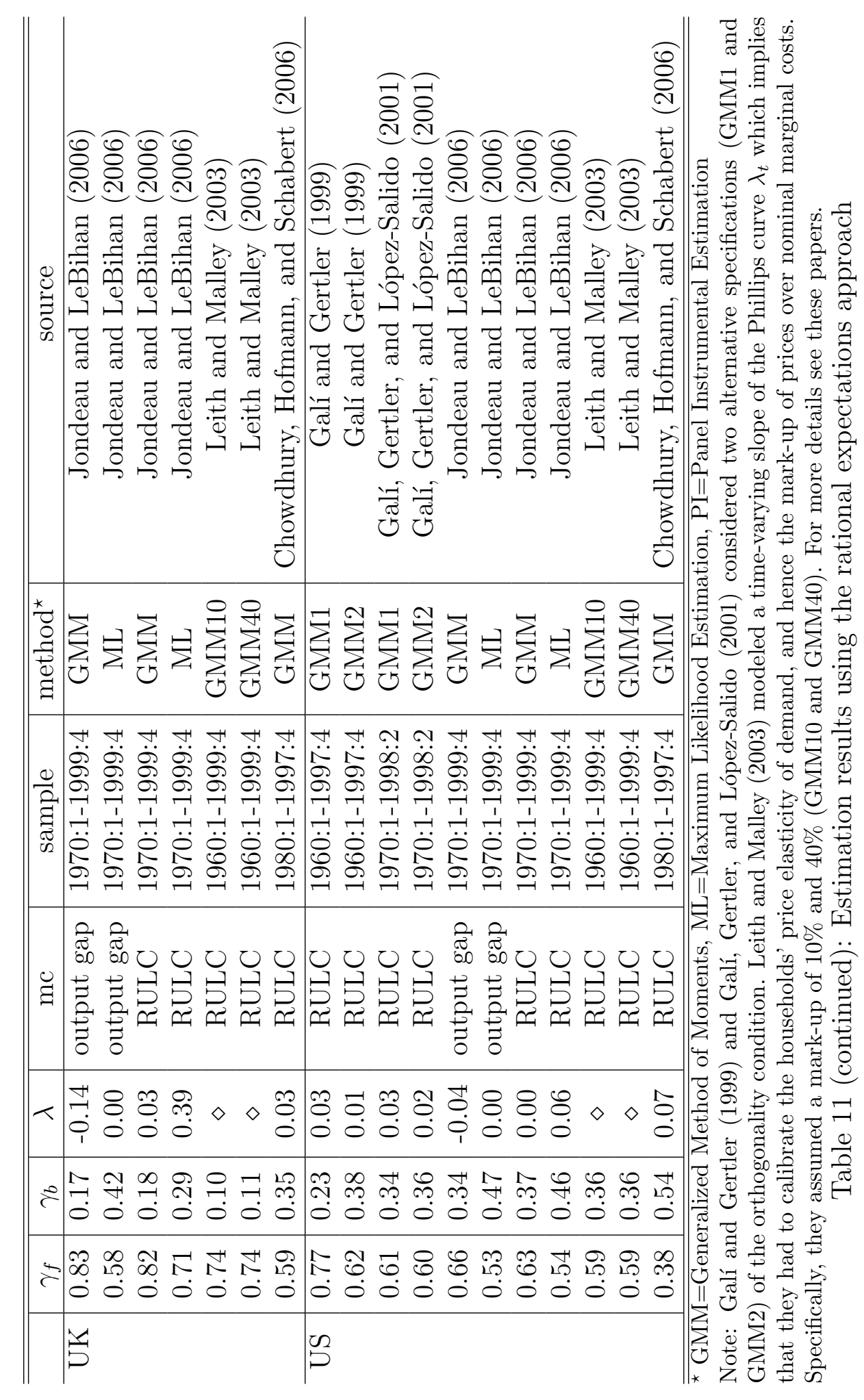


The second interesting result of our paper is that, except for France, the degree of forward-looking behavior is found to be lower when using survey data instead of imposing rational expectations. And this finding is qualitatively confirmed by the other survey data studies. In table 12 we calculated averages of the estimates of $\gamma_{f}$ that were presented in tables 10 and 11 . Germany is a very striking example. While studies using the rational expectations approach find an average coefficient for $\gamma_{f}$ of 0.70 , our estimates are much lower, with an average value of 0.26. Reckwerth (1997) who uses another source for German inflation expectations also finds estimates for $\gamma_{f}$ which are smaller than under the rational expectations approach. The results for the US point into the same direction. While the average value for $\gamma_{f}$ under rational expectations is 0.59 , our regressions returned an average value of 0.40. Again, this tendency of a lower degree of forwardness when survey data is used, is confirmed by other studies.

There are three possible explanations for the differences in the estimated coefficients $\gamma_{f}$ and $\gamma_{b}$. First, our sample only starts at the beginning of the 1990s whereas most of the other studies begin in 1960 or 1970. Since the price setting behavior of firms depends to a large extent on expectations about future inflation, the monetary policy regime that is in force plays a crucial role for the estimated behavioral parameters. Most of the countries in our sample, however, underwent one or even more significant changes in their monetary policy strategy so that lower estimates for $\gamma_{f}$ for the period 1993 to present cannot be excluded from the GMM results. Unfortunately, stability of the results is rarely discussed in these papers.

Second, non-rationalities which are incorporated in survey expectations may matter for the price-setting process of firms. In section 3.1 we showed that inflation expectations of the Ifo WES are inefficient and in some cases even biased predictors of future inflation. This is in clear contrast to the assumption made when GMM is used as estimation technique. An indication in favor of this explanation are the results of studies using survey data listed in table 10. Their samples range from the 1960s to 1999 or even longer which is more or less similar to the time span covered by most rational expectations studies, and their average point estimates for $\gamma_{f}$ are close to ours. A possible explanation is put forward by Galí and Gertler (1999), Galí, Gertler, and López-Salido (2005) and also Rudd and Whelan (2005) who argue that GMM estimates for $\gamma_{f}$ may be biased upwards if important variables are omitted from the model so that the error term in the econometric model contains information about future inflation. Rudd and Whelan (2005) even come to the conclusion that the purely forward-looking model cannot characterize inflation dynamics. Our estimations are robust to non-rationalities as they do not rely on the orthogonality of the expectational error and the set of 


\begin{tabular}{l|rrrrrr}
\hline \hline & \multicolumn{1}{|c}{$\begin{array}{c}\text { Euro } \\
\text { zone }\end{array}$} & France & \multicolumn{1}{c}{ Ger } & Italy & UK & US \\
& \multicolumn{7}{c}{-many } & & & \\
\hline Ifo WES & 0.52 & 0.77 & 0.26 & 0.26 & 0.48 & 0.40 \\
& $( \pm 0.02)$ & $( \pm 0.01)$ & $( \pm 0.03)$ & $( \pm 0.00)$ & $( \pm 0.03)$ & $( \pm 0.05)$ \\
RE approach & 0.65 & 0.66 & 0.70 & 0.52 & 0.72 & 0.59 \\
& $( \pm 0.12)$ & $( \pm 0.11)$ & $( \pm 0.12)$ & $( \pm 0.11)$ & $( \pm 0.09)$ & $( \pm 0.09)$ \\
other & & & & & & - \\
surveys & 0.49 & - & 0.43 & - & & 0.43 \\
& $( \pm 0.00)$ & & $( \pm 0.00)$ & & & $( \pm 0.13)$ \\
\hline \hline
\end{tabular}

Note: The values in parentheses refer to the standard deviation of the point estimates.

Table 12: Summary of estimates for $\gamma_{f}$

instruments. We take our estimates as evidence of the presence of a forwardlooking component in inflation dynamics. Although its importance varies between the countries that we are considering, it clearly remains significant.

Third, in order to be able to apply subjective inflation expectations to our theoretical framework described in section 2.2 we had to assume that the survey responses are a representative subset of the expectations of all firms. However, this assumption has recently become subject to criticism. Nunes (2005), for example, argues that firms are likely to have a higher degree of rationality than survey respondents since the latter must predict the aggregate evolution of a basket of prices without any specific knowledge of each price determinant. From this follows that the observed deviation of survey data from rational expectations should not be taken as an argument against the rational expectations approach.

One way to check whether the first or the second explanation is relevant is to apply the GMM approach to a shorter sample. Starting in 1993 instead of 1960 or 1970 would provide some evidence on the stability of the structural parameters. The problem, however, is that GMM has very poor small sample properties, meaning that estimators are often found to be biased, widely dispersed and sensitive to the normalization of the orthogonality conditions as well as to the choice of the instruments (see for example Fuhrer, Moore, and Schuh (1995) for a recent paper on this issue).

\section{Conclusions}

In this paper we provided evidence for the fit of the hybrid New Keynesian Phillips curve for selected Euro zone countries, the US and the UK. Instead of imposing rational expectations and estimating the Phillips curve by the Generalized Method of Moments, we followed Roberts (1997) and Adam and 
Padula (2003) and used direct measures of inflation expectations from the Ifo World Economic Survey.

Our main findings are that in comparison with the rational expectations approach backward-looking behavior is more relevant for most countries in our sample and that the use of survey data for inflation expectations yields a positive slope of the Phillips curve. The significance of the respective measure for marginal cost and, hence, the preferred measure, however, depends on the country considered. There is no case where marginal cost has a significantly negative effect on inflation. On the whole, using the output gap as a measure for marginal cost leads to an upward sloping New Keynesian Phillips curve which is consistent with theory.

One explanation for these results is that non-rationalities which are incorporated in survey expectations may matter for the price-setting process of firms. If we are correct in using a survey among economic experts for approximating firms' expectations, such an explanation would have an important impact on the policy conclusions that are typically drawn on the basis of models where agents are assumed to form expectations rationally. Some first attempts to model deviations from perfectly rational expectations have been developed by Mankiw and Reis (2002). In their sticky-information model they impose a constraint on the information that people use when forming expectations. They assume that in each period there is a fixed probability that a person updates his information set; otherwise he continues to set prices on outdated information. In Ball, Mankiw, and Reis (2003) they provide a normative monetary policy analysis that accounts for these deviations from rationality. And their central conclusion is that under such a setting the central bank should target the price level rather than the inflation rate. Thus, in future work it would be interesting to investigate in more detail how the private sector actually forms inflation expectations. 


\section{Appendix}

\section{A Derivation of Equation (9)}

Equation (9) can be derived by subtracting equation (7) from equation (6)

$$
F_{t}^{i}\left[p_{t+1}^{f}\right]-p_{t}^{f}=F_{t}^{i}\left[\pi_{t+1}^{f}\right]=\frac{1}{I} F_{t}^{i}\left[\sum_{h=1}^{I}\left(p_{t+1}^{f, h}-p_{t}^{f, h}\right)\right]
$$

and by replacing $p_{t+1}^{f, h}$ and $p_{t}^{f, h}$ with the first expression of equation (5):

$$
\begin{aligned}
F_{t}^{i}\left[\pi_{t+1}^{f}\right]= & \frac{1-\beta \theta}{I} F_{t}^{i}\left[\sum _ { h = 1 } ^ { I } \left\{F_{t+1}^{h}\left[\sum_{k=0}^{\infty}(\beta \theta)^{k}\left(m c_{t+k+1}+p_{t+k+1}\right)\right]-\right.\right. \\
& \left.\left.-F_{t}^{h}\left[\sum_{k=0}^{\infty}(\beta \theta)^{k}\left(m c_{t+k}+p_{t+k}\right)\right]\right\}\right] .
\end{aligned}
$$

Applying the law of iterated expectations (equation (8)) this expression can be simplified to

$F_{t}^{i}\left[\pi_{t+1}^{f}\right]=\frac{1-\beta \theta}{I} F_{t}^{i}\left[\sum_{h=1}^{I}\left\{(1-\beta \theta) F_{t}^{h}\left[\sum_{k=0}^{\infty}(\beta \theta)^{k}\left(m c_{t+k+1}+p_{t+k+1}\right)\right]-\left(m c_{t}+p_{t}\right)\right\}\right]$.

Replacing $(1-\beta \theta) F_{t}^{h}\left[\sum_{k=0}^{\infty}(\beta \theta)^{k}\left(m c_{t+k+1}+p_{t+k+1}\right)\right]$ with $p_{t+1}^{f, h}$ (equation (5)) and using equation (6) finally gives equation (9):

$$
F_{t}^{i}\left[\pi_{t+1}^{f}\right]=(1-\beta \theta)\left(F_{t}^{i}\left[p_{t+1}^{f}\right]-m c_{t}-p_{t}\right) .
$$

\section{B Derivation of Equation (10)}

Equation (10) can be derived by aggregating equation (3) to

$$
p_{t}^{*}=(1-\omega) p_{t}^{f}+\omega p_{t}^{b},
$$

solving the resulting expression for $p_{t}^{f}$ and replacing $p_{t}^{b}$ with equation (4):

$$
p_{t}^{f}=\frac{p_{t}^{*}-\omega\left(p_{t-1}^{*}+p_{t-1}-p_{t-2}\right)}{1-\omega} .
$$

Next, solve equation (2) for $p_{t}^{*}$ and replace it in the preceding expression. After a little algebra, equation (10) is obtained:

$$
p_{t}^{f}=\frac{p_{t}+(\theta \omega-2 \omega-\theta) p_{t-1}+\omega p_{t-2}}{(1-\theta)(1-\omega)} .
$$




\section{Derivation of Equation (12)}

Inserting equation (11) on the right-hand-side of equation (9) gives

$$
F_{t}^{i}\left[\pi_{t+1}^{f}\right]=(1-\beta \theta)\left(\frac{F_{t}^{i}\left[\pi_{t+1}\right]-\omega \pi_{t}}{(1-\theta)(1-\beta)}-m c_{t}\right) .
$$

Forming average subjective expectations, $\bar{F}_{t}[\cdot]=(1 / I) \sum_{i=1}^{I} F_{t}^{i}[\cdot]$, yields

$$
\bar{F}_{t}\left[\pi_{t+1}^{f}\right]=(1-\beta \theta)\left(\frac{\bar{F}_{t}\left[\pi_{t+1}\right]-\omega \pi_{t}}{(1-\theta)(1-\beta)}-m c_{t}\right) .
$$

An alternative expression for $F_{t}^{i}\left[\pi_{t+1}^{f}\right]$ can de derived by subtracting equation (10) from equation (11):

$$
F_{t}^{i}\left[\pi_{t+1}^{f}\right]=\frac{F_{t}^{i}\left[\pi_{t+1}\right]+(\theta \omega-2 \omega-\theta) \pi_{t}+\omega \pi_{t-1}}{(1-\theta)(1-\omega)} .
$$

Forming average subjective expectations yields

$$
\bar{F}_{t}\left[\pi_{t+1}^{f}\right]=\frac{\bar{F}_{t}\left[\pi_{t+1}\right]+(\theta \omega-2 \omega-\theta) \pi_{t}+\omega \pi_{t-1}}{(1-\theta)(1-\omega)} .
$$

Equating both expressions for $\bar{F}_{t}\left[\pi_{t+1}^{f}\right]$ and solving for $\pi_{t}$ finally results in equation (12):

$$
\pi_{t}=\gamma_{f} \bar{F}_{t}\left[\pi_{t+1}\right]+\gamma_{b} \pi_{t-1}+\lambda m c_{t}
$$

where

$$
\begin{gathered}
\gamma_{f}=\frac{\beta \theta}{\theta+\omega[1-\theta(1-\beta)]}, \\
\gamma_{b}=\frac{\omega}{\theta+\omega[1-\theta(1-\beta)]}, \\
\lambda=\frac{(1-\omega)(1-\theta)(1-\beta \theta)}{\theta+\omega[1-\theta(1-\beta)]} .
\end{gathered}
$$




\section{References}

Adam, K., And M. Padula (2003): "Inflation Dynamics and Subjective Expectations in the United States," ECB Working Paper No. 222.

Angeloni, I., And M. Ehrmann (2004): "Euro Area Inflation Differentials," ECB Working Paper No. 388.

Ball, L., N. G. Mankiw, and R. Reis (2003): "Monetary Policy for Inattentive Economies," NBER Working Paper No. 9491.

Benigno, P., and J. D. López-Salido (2002): "Inflation Persistence and Optimal Monetary Policy in the Euro Area," ECB Working Paper No. 178.

Calvo, G. A. (1983): "Staggered Contracts in a Utility-Maximizing Framework," Journal of Monetary Economics, 12(3), 383-398.

Carlson, J., and M. Parkin (1975): "Inflation Expectations," Economica, 42(166), 123-138.

Chowdhury, I., M. Hofmann, and A. Schabert (2006): "Inflation Dynamics and the Cost Channel of Monetary Policy Transmission," European Economic Review, fothcoming.

Forsells, M., And G. Kenny (2002): "The Rationality of Consumers' Inflation Expectations: Survey-Based Evidence for the Euro Area," ECB Working Paper No. 163.

Fuhrer, F., And G. Moore (1995): "Inflation Persistence," The Quarterly Journal of Economics, 110(1), 127-159.

Fuhrer, J. C., G. R. Moore, and S. D. Schuh (1995): "Estimating the Linear-quadratic Inventory Model: Maximum Likelihood versus Generalized Method of Moments," Journal of Monetary Economics, 35(1), $115-157$.

Galí, J. (2003): "New Perspectives on Monetary Policy, Inflation, and the Business Cycle," in Advances in Economics and Econometrics: Theory and Applications, Eighth World Congress, Volume III, ed. by M. Dewatripont, L. P. Hansen, and S. J. Turnovsky, pp. 151-197. Cambridge University Press, Cambridge.

Galí, J., And M. Gertler (1999): "Inflation Dynamics: A Structural Econometric Analysis," Journal of Monetary Economics, 44(2), 195-222. 
Galí, J., M. Gertler, And J. D. López-Salido (2001): "European Inflation Dynamics," European Economic Review, 44(7), 1237-1270.

- (2003): "Erratum to 'European Inflation Dynamics'," European Economic Review, 47(4), 759-760.

(2005): "Robustness of the Estimates of the Hybrid New-Keynesian Phillips Curve," Journal of Monetary Economics, 52(6), 1107-1118.

Hausman, J. A. (1978): "Specification Tests in Econometrics," Econometrica, 46(6), 1251-1271.

Henzel, S., and T. WollmershäUser (2006): "Quantifying Inflation Expectations with the Carlson-Parkin Method - A Survey-based Determination of the Just Noticeable Difference," Journal of Business Cycle Measurement and Analysis, forthcoming.

Jondeau, E., and H. LeBihan (2006): "Testing for the New Keynesian Phillips Curve: Additional International Evidence," Economic Modelling, $22(3), 521-550$.

Leith, C., And J. Malley (2003): "Estimated Open Economy New Keynesian Phillips Curves for the G7," CESifo Working Paper No. 834.

Mankiw, N. G., And R. Reis (2002): "Sticky Information versus Sticky Prices: A Proposal to Replace the New Keynesian Phillips Curve," Quarterly Journal of Economics, 117(4), 1295-1328.

Mavroeidis, S. (2005): "Identification Issues in Forward-Looking Models Estmated by GMM, with an Application to the Phillips Curve," Journal of Money, Credit, and Banking, 37(3), 421-448.

Muth, J. F. (1961): "Rational Expectations and the Theory of Price Movements," Econometrica, 29(3), 315-335.

Nunes, R. C. (2005): "Inflation Dynamics: The Role of Expectations," mimeo, University of Pompeu Fabra.

Palovitita, M. (2004): "Inflation Dynamics in the Euro Area and the Role of Expectations: Further Results," Bank of Finland Discussion Paper No. $21 / 2004$.

ReCKWERTH, J. (1997): "Der Zusammenhang zwischen Inflation und Output in Deutschland unter Bercksichtigung der Inflationswerwartungen," Deutsche Bundesbank Discussion Paper No. 5/97. 
Roberts, J. M. (1997): "Is Inflation sticky?," Journal of Monetary Economics, 39(2), 173-196.

Rudd, J., And K. Whelan (2005): "New Tests of the New-Keynesian Phillips curve," Journal of Monetary Economics, 52(6), 1167-1181.

Rumler, F. (2005): "Estimates of the Open Economy New Keynesian Phillips Curve for Euro Area Countries," ECB Working Paper No. 496.

Sbordone, A. M. (2005): "Do Expected Future Marginal Costs Drive Inflation Dynamics?," Journal of Monetary Economics, 52(6), 1183-1197.

SeITz, H. (1988): "The Estimation of Inflation Forecasts from Business Survey Data," Applied Economics, 20(4), 427-438.

SHEA, J. (1997): "Instrument Relevance in Multivariate Linear Models: A Simple Measure," The Review of Economics and Statistics, 79(2), 348-352.

Smets, F. (2003): "Maintaining Price Stability: How Long is the Medium Term," Journal of Monetary Economics, 50(6), 1293-1309.

Walsh, C. E. (2003): Monetary Theory and Policy. The MIT Press, Cambridge.

Zhang, C., And D. R. Osborn (2005): "Observed Inflation Forecasts and the New Keynesian Phillips Curve," mimeo, University of Manchester. 


\section{CESifo Working Paper Series}

(for full list see www.cesifo-group.de)

1633 Michiel Evers, Ruud A. de Mooij and Daniel J. van Vuuren, What Explains the Variation in Estimates of Labour Supply Elasticities?, December 2005

1634 Matthias Wrede, Health Values, Preference Inconsistency, and Insurance Demand, December 2005

1635 Hans Jarle Kind, Marko Koethenbuerger and Guttorm Schjelderup, Do Consumers Buy Less of a Taxed Good?, December 2005

1636 Michael McBride and Stergios Skaperdas, Explaining Conflict in Low-Income Countries: Incomplete Contracting in the Shadow of the Future, December 2005

1637 Alfons J. Weichenrieder and Oliver Busch, Artificial Time Inconsistency as a Remedy for the Race to the Bottom, December 2005

1638 Aleksander Berentsen and Christopher Waller, Optimal Stabilization Policy with Flexible Prices, December 2005

1639 Panu Poutvaara and Mikael Priks, Violent Groups and Police Tactics: Should Tear Gas Make Crime Preventers Cry?, December 2005

1640 Yin-Wong Cheung and Kon S. Lai, A Reappraisal of the Border Effect on Relative Price Volatility, January 2006

1641 Stefan Bach, Giacomo Corneo and Viktor Steiner, Top Incomes and Top Taxes in Germany, January 2006

1642 Johann K. Brunner and Susanne Pech, Optimum Taxation of Life Annuities, January 2006

1643 Naércio Aquino Menezes Filho, Marc-Andreas Muendler and Garey Ramey, The Structure of Worker Compensation in Brazil, with a Comparison to France and the United States, January 2006

1644 Konstantinos Angelopoulos, Apostolis Philippopoulos and Vanghelis Vassilatos, RentSeeking Competition from State Coffers: A Calibrated DSGE Model of the Euro Area, January 2006

1645 Burkhard Heer and Bernd Suessmuth, The Savings-Inflation Puzzle, January 2006

1646 J. Stephen Ferris, Soo-Bin Park and Stanley L. Winer, Political Competition and Convergence to Fundamentals: With Application to the Political Business Cycle and the Size of Government, January 2006 
$1647 \mathrm{Yu}-\mathrm{Fu}$ Chen, Michael Funke and Kadri Männasoo, Extracting Leading Indicators of Bank Fragility from Market Prices - Estonia Focus, January 2006

1648 Panu Poutvaara, On Human Capital Formation with Exit Options: Comment and New Results, January 2006

1649 Anders Forslund, Nils Gottfries and Andreas Westermark, Real and Nominal Wage Adjustment in Open Economies, January 2006

1650 M. Hashem Pesaran, Davide Pettenuzzo and Allan G. Timmermann, Learning, Structural Instability and Present Value Calculations, January 2006

1651 Markku Lanne and Helmut Luetkepohl, Structural Vector Autoregressions with Nonnormal Residuals, January 2006

1652 Helge Berger, Jakob de Haan and Jan-Egbert Sturm, Does Money Matter in the ECB Strategy? New Evidence Based on ECB Communication, January 2006

1653 Axel Dreher and Friedrich Schneider, Corruption and the Shadow Economy: An Empirical Analysis, January 2006

1654 Stefan Brandauer and Florian Englmaier, A Model of Strategic Delegation in Contests between Groups, January 2006

1655 Jan Zápal and Ondřej Schneider, What are their Words Worth? Political Plans and Economic Pains of Fiscal Consolidations in New EU Member States, January 2006

1656 Thiess Buettner, Sebastian Hauptmeier and Robert Schwager, Efficient Revenue Sharing and Upper Level Governments: Theory and Application to Germany, January 2006

1657 Daniel Haile, Abdolkarim Sadrieh and Harrie A. A. Verbon, Cross-Racial Envy and Underinvestment in South Africa, February 2006

1658 Frode Meland and Odd Rune Straume, Outsourcing in Contests, February 2006

1659 M. Hashem Pesaran and Ron Smith, Macroeconometric Modelling with a Global Perspective, February 2006

1660 Alexander F. Wagner and Friedrich Schneider, Satisfaction with Democracy and the Environment in Western Europe - a Panel Analysis, February 2006

1661 Ben J. Heijdra and Jenny E. Ligthart, Fiscal Policy, Monopolistic Competition, and Finite Lives, February 2006

1662 Ludger Woessmann, Public-Private Partnership and Schooling Outcomes across Countries, February 2006

1663 Topi Miettinen and Panu Poutvaara, Political Parties and Network Formation, February 2006 
1664 Alessandro Cigno and Annalisa Luporini, Optimal Policy Towards Families with Different Amounts of Social Capital, in the Presence of Asymmetric Information and Stochastic Fertility, February 2006

1665 Samuel Muehlemann and Stefan C. Wolter, Regional Effects on Employer Provided Training: Evidence from Apprenticeship Training in Switzerland, February 2006

1666 Laszlo Goerke, Bureaucratic Corruption and Profit Tax Evasion, February 2006

1667 Ivo J. M. Arnold and Jan J. G. Lemmen, Inflation Expectations and Inflation Uncertainty in the Eurozone: Evidence from Survey Data, February 2006

1668 Hans Gersbach and Hans Haller, Voice and Bargaining Power, February 2006

1669 Françoise Forges and Frédéric Koessler, Long Persuasion Games, February 2006

1670 Florian Englmaier and Markus Reisinger, Information, Coordination, and the Industrialization of Countries, February 2006

1671 Hendrik Hakenes and Andreas Irmen, Something out of Nothing? Neoclassical Growth and the 'Trivial' Steady State, February 2006

1672 Torsten Persson and Guido Tabellini, Democracy and Development: The Devil in the Details, February 2006

1673 Michael Rauber and Heinrich W. Ursprung, Evaluation of Researchers: A Life Cycle Analysis of German Academic Economists, February 2006

1674 Ernesto Reuben and Frans van Winden, Reciprocity and Emotions when Reciprocators Know each other, February 2006

1675 Assar Lindbeck and Mats Persson, A Model of Income Insurance and Social Norms, February 2006

1676 Horst Raff, Michael Ryan and Frank Staehler, Asset Ownership and Foreign-Market Entry, February 2006

1677 Miguel Portela, Rob Alessie and Coen Teulings, Measurement Error in Education and Growth Regressions, February 2006

1678 Andreas Haufler, Alexander Klemm and Guttorm Schjelderup, Globalisation and the Mix of Wage and Profit Taxes, February 2006

1679 Kurt R. Brekke and Lars Sørgard, Public versus Private Health Care in a National Health Service, March 2006

1680 Dominik Grafenhofer, Christian Jaag, Christian Keuschnigg and Mirela Keuschnigg, Probabilistic Aging, March 2006 
1681 Wladimir Raymond, Pierre Mohnen, Franz Palm and Sybrand Schim van der Loeff, Persistence of Innovation in Dutch Manufacturing: Is it Spurious?, March 2006

1682 Andrea Colciago, V. Anton Muscatelli, Tiziano Ropele and Patrizio Tirelli, The Role of Fiscal Policy in a Monetary Union: Are National Automatic Stabilizers Effective?, March 2006

1683 Mario Jametti and Thomas von Ungern-Sternberg, Risk Selection in Natural Disaster Insurance - the Case of France, March 2006

1684 Ken Sennewald and Klaus Waelde, "Itô's Lemma" and the Bellman Equation for Poisson Processes: An Applied View, March 2006

1685 Ernesto Reuben and Frans van Winden, Negative Reciprocity and the Interaction of Emotions and Fairness Norms, March 2006

1686 Françoise Forges, The Ex Ante Incentive Compatible Core in Exchange Economies with and without Indivisibilities, March 2006

1687 Assar Lindbeck, Mårten Palme and Mats Persson, Job Security and Work Absence: Evidence from a Natural Experiment, March 2006

1688 Sebastian Buhai and Coen Teulings, Tenure Profiles and Efficient Separation in a Stochastic Productivity Model, March 2006

1689 Gebhard Kirchgaessner and Silika Prohl, Sustainability of Swiss Fiscal Policy, March 2006

1690 A. Lans Bovenberg and Peter Birch Sørensen, Optimal Taxation and Social Insurance in a Lifetime Perspective, March 2006

1691 Moritz Schularick and Thomas M. Steger, Does Financial Integration Spur Economic Growth? New Evidence from the First Era of Financial Globalization, March 2006

1692 Burkhard Heer and Alfred Maussner, Business Cycle Dynamics of a New Keynesian Overlapping Generations Model with Progressive Income Taxation, March 2006

1693 Jarko Fidrmuc and Iikka Korhonen, Meta-Analysis of the Business Cycle Correlation between the Euro Area and the CEECs, March 2006

1694 Steffen Henzel and Timo Wollmershaeuser, The New Keynesian Phillips Curve and the Role of Expectations: Evidence from the Ifo World Economic Survey, March 2006 